\title{
Does bleeding affect patient reported outcome measures in patients with myelodysplasia or hematologic malignancies: a systematic review.
}

Lise J Estcourt ${ }^{1,2}$, Deborah Pinchon ${ }^{3,4}$, Emily Symington ${ }^{5}$, Anne MKelly ${ }^{6}$, Carolyn Doree ${ }^{1,2}$, Susan

Brunskill ${ }^{1,2}$, Liz Glidewell ${ }^{7}$, Simon Stanworth ${ }^{1,2}$

1. Radcliffe Department of Medicine, University of Oxford, Oxford UK

2. Systematic Reviews Initiative, NHS Blood and Transplant, Oxford, UK

3. Hull and East Yorkshire NHS Trust, Hull, UK

4. King Edward Memorial Hospital, Perth, Western Australia, Australia

5. Cambridge University Hospitals NHS Foundation Trust, UK

6. Division of Transfusion Medicine, Department of Haematology, University of Cambridge, UK

7. Leeds Institute of Health Sciences, University of Leeds, UK

Corresponding Author \& author responsible for reprint requests

Lise J Estcourt

NHS Blood and Transplant

Level 2

John Radcliffe Hospital

Oxford

OX3 9BQ

Tel: 01865387974

Fax: 01865387957

Lise.estcourt@nhsbt.nhs.uk

\section{Funding}

NHS Blood and Transplant

\section{Conflicts of Interest}

The authors declare no conflicts of interest

Word count

3997 


\section{Abstract (235 words)}

\section{Background}

Relatively minor bleeding (e.g. bruising/petechiae) may cause patient distress. This systematic review's objective was to assess whether bleeding affects health-related quality of life (HRQoL) orillness perceptions/representations (IPs) in patients with hematologic malignancies or myelodysplasia.

\section{Study Design and Methods}

We searched, in full, 12 electronic databases (including CENTRAL; MEDLINE; EMBASE) up to $7^{\text {th }}$ January 2013 for eligible randomised-controlled trials (RCTs), prospective cohort, and cross-sectional studies.

\section{Results}

6247 studies were initially identified, 5945 studies were excluded on the basis of the abstract. 302 full text articles were evaluated independently by 2 reviewers, of these, 6 studies within 7 citations were eligible for inclusion. Two studies are still in progress, 4 studies wi thin 5 citations were included in this review (1RCT; 1 prospective observational study; 1 interview study; and 1 web-based survey). None of the included studies were designed to assess the impact bleeding had on HRQoL or IPs. The web-based survey and observational study used two new patient-reported outcome scales which specifically assessed patient distress/concern due to bleeding. The majority of patients within these two studies either did not experience bleeding or were not severely th rombocytopenic.

\section{Conclusion}

There is insufficient evidence to demonstrate whether bleeding is a significant clinical problem that affects patients' HRQoL or IPs in either patients with myelodysplasia or patients with hematologic malignancies. Rigorously designed studies to assess the scale of this problem in both these groups of patients are required.

Quality of life and bleeding 


\section{Keywords:}

Bleeding; Quality of life; Thrombocytopenia; Myelodysplasia; Hematologic malignancy, Illness Perceptions/Representations

Quality of life and bleeding 


\section{Background}

Clinicians may not realise that relatively minor bleeding could cause patient distress. Petechiae are seen by doctors as a relatively trivial manifestation of thrombocytopenia but patients could see them as an outward sign of their illness and therefore distressing.

Any type of supportive care should explicitly assess quality of life. ${ }^{1}$ The majority of platelet transfusions (69\%) given to patients with hematologic malignancies or myelodysplasia (MDS) are to prevent bleeding (i.e. supportive care), ${ }^{2}$ usually when their platelet count is $<10 \times 10^{9} /$ Lunless they have other risk factors for bleeding. ${ }^{2,3}$ There have been two recent large randomized-controlled trials (RCTs) that compared the use of prophylactic platelet transfusions versus therapeutic-only platel et transfusions..$^{4,5}$ Both showed that prophylactic platelet transfusions reduced bleeding (WHO grade 2 bleeding or above $43 \%$ vs. 50\%, ${ }^{5}$ but this strategy required significantly more platelet transfusions (mean number/patient 3 vs. 1.7: P<0.001). ${ }^{5}$ It is essential to determine whether any benefits of platelet transfusions (e.g. reduced bleeding and patient distress) are outweighed by their costs (e.g. risks of transfusion). Oneway to measure patient distress would be via measurement of health-related quality of life (HRQoL) or illness perceptions/representations (IPs).

Recent data from the EXTEND ${ }^{6}$ and RAISE ${ }^{7}$ RCTs has shown that bleeding has a significant impact on HRQoL in patients with immune thrombocytopenia (ITP). ${ }^{8}$ However, no platelet transfusion study within two recent systematic reviews assessed patients' HRQoL or IPs as an outcome measure. ${ }^{9,10}$ The majority of bleeding seen within these platelet transfusion studies is considered minor or moderate by researchers and clinicians (World Health Authority (WHO) Grade 1 or 2).4,11,12 Also, skin bleeding is often not considered clinically significant. ${ }^{4,12-15}$ These trials used bleeding scales to produce a more objective assessment of bleeding, however these scales do not take into account the impact bleeding may have on the patients' 'qual ity of life'. For example, a new bleeding grading system (Bleeding Severity Measurement Scale (BSMS)) did not consider a nosebleed that did not require nasal packing or a transfusion as clinically significant. ${ }^{12}$ However, for patients with hematologic malignancies or myel odysplasia we do not know what effect this minor or moderate bleeding has on patients' symptom distress or HRQoL. Patients with ITP differ significantly from patients with hematologic malignancies or MDS. The main 
symptom patients with ITP will have is bleeding, whereas patients with hematologic malignancies or MDS often have a plethora of other symptoms due to their diagnosis or treatment. The incremental impact of bleeding (usually WHO grade 1 or 2) on HRQoL or symptom distress in patients with hematologic malignancies or MDS may be minimal.

Health Related Quality of Life (HRQoL) refers to how an individual's well-being (all emotional, social, and physical aspects of the individual's life) may be impacted over time by a disease, a disability, or a disorder. ${ }^{16}$ It is inherently subjective and is best measured from the patient's perspective.$^{1}$ Because it is multidimensional, its measurement requires the investigator to ask about a range of areas of the patient's life; including physical, emotional, and social well -being as well as functional ability. ${ }^{1} \mathrm{HRQoL}$ is now usually measured quantitatively using questionnaires (patient-reported outcome measures (PROMS)). ${ }^{16}$ These questionnaires should meet certain quality criteria regarding their reliability and validity in the patient population being studied. ${ }^{17}$ They can be divided into two main types: generic instruments (e.g. SF-36, 36-Item Short Form Health Survey) $;{ }^{18}$ and disease or disorder specific instruments (e.g. FACT-BMT, Functional Assessment of Cancer Therapy - Bone Marrow Transplantation). ${ }^{19}$

IIIness representations/perceptions are patients' beliefs and expectations about an illness or physical symptom. They are central to Leventhal's Common-Sense Model (CSM) of IIIness Representation (also called Self-Regulation Theory)..$^{20-22}$ The CSM identifies the factors involved in the patient's processing of information regarding their disease or illness, how this information is integrated to providea 'lay' view of the illness and how this 'lay' view guides coping behaviours and outcomes (Figure 1$).{ }^{23}$ Research has identified six cognitive components of illness representations/perceptions (these will bereferred to as perceptions throughout the rest of the review) ${ }^{21,22,24}$ A popular quantitative tool used to elicit illness perceptions is the Illness Perception Questionnaire (IPQ). ${ }^{25}$ This has been revised to include emotional representations and illness coherence (IPQ-R, 
Revised IIIness Perception Questionnaire). ${ }^{26}$ Across the questionnaires, high scores on Consequences, Identity, Emotional Representations, Timeline Acute/Chronic and Timeline Cyclical dimensions typically represent more negative beliefs. Conversely, high scores on the Coherence, Personal Control and Treatment Control dimensions represent more positive beliefs. ${ }^{27}$

Why it is important to do this review

There is a need to understand the effect, if any, of bleeding on patient's illness perceptions/representations (IPs) and HRQoL, and ul timately upon clinical outcomes. This would enable a more robust evaluation of platel et transfusion strategies and disease treatments in the future.

\section{Objectives}

Primary: To assess whether bleeding affects HRQoL or IPs in patients with hematologic malignancies or myelodysplasia (MDS).

Secondary: To determine: methodological quality of included studies and explore any difference in patient reported outcomes with regards to bleeding; whether quantitative measures of HRQoL or IP have been developed specifically related to bleeding; and whether any studies have used interventions to reduce symptom distress.

\section{Methods}

\section{Protocol and registration}

Full details of the inclusion criteria and methods for the analysis were pre-specified and documented in a protocol [PROSPERO (CRD 42011001446) and published on-line

(http://www.crd.york.ac.uk/prospero/)].

Quality of life and bleeding 


\section{Criteria}

Types ofstudies:

Randomized controlled trials (RCTs), prospective cohort studies and prospective cross-sectional studies were included in this review. These studies could be quantitative or qualitative in nature. Retrospective studies, case reports, animal studies, laboratory studies, and reviews were excluded from the review.

\section{Types ofparticipants}

Patients of any age were included if they had MDS or a hematologic malignancy and were severely thrombocytopenic ( $\leq 50 \times 10^{9} /$ I for at least 5 days) or expected to become severely thrombocytopenic due to their treatment. HRQoL or illness perception evaluation and bleeding had to be primary or secondary outcomes in the original study.

Studies were excluded if patients had other hematologic disorders; patients were not thrombocytopenic; or only family members/care-givers were asked about HRQoL. If studies consisted of mixed populations of patients, with diagnoses of solid tumors or non-malignant hematologic disorders, only data from the hematologic malignancy/MDS sub-groups were included. If sub-group data was not provided (after contacting the study authors), the study was excluded if fewer than $80 \%$ of participants had hematologic malignancies/MDS.

Types ofoutcome measures

Primary outcomes

- HRQoL or IPs and its relation to bleeding.

Secondary outcomes

- Number and severity of bleeding episodes

- Mortality (all cause and secondary to bleeding)

Quality of life and bleeding 


\section{Search methods}

Nine electronic databases (including MEDLINE (1948 to 2013); EMBASE (1980 to 2013); CINAHL (1982 to 2013); Transfusion Evidence Library (1980 to 2013)), as well as three electronic trials databases were searched in full up to $7^{\text {th }}$ January 2013. There was no restriction on language or publication period. (See Appendix 1 for Search strategies). Database searching was augmented by hand-searching reference lists of all included studies, relevant review articles, and current treatment guidelines.

\section{Data collection and analysis}

\section{Selection of studies}

All electronically derived citations and abstracts of papers identified by the review search strategy were initiallyscreened by one reviewer (CD) and duplicates were removed. The abstracts were then screened for relevancy by another reviewer (LE, AK or DP). Twenty per cent of these abstracts were selected randomly and these were then screened independently by a third reviewer (LE, AK or DP): any disagreements were resolved by discussion. Studies not meeting the inclusion criteria were excluded at this stage. The full texts of all potentially relevant studies were formally assessed for eligibility by any two out of four independent reviewers (LE, AK, DP, ES): any disagreements were resolved by discussion. Further information was sought from the study authors when the study reports contained insufficient data to enable a decision to be made about eligibility for this review. All studies that failed to meet our eligibility criteria were detailed in a table of excluded studies. Methodological quality was not an exclusion criterion.

\section{Data extraction and management}

Data extraction was conducted according to the guidelines proposed by The Cochrane Collaboration, ${ }^{28}$ by two authors working independently (DP, ES). Disagreements between the review authors were resolved by consensus. A third review author (LE) gave her opinion if the first two authors could not 
reach a consensus. The review authors were not blinded to names of authors, institutions, journals, or the outcomes of the studies. Data were extracted using a standardised data extraction form designed specifically for use in this review (Appendix 2). When study reports did not provide sufficient information, authors and study groups were contacted for additional details.

\section{Assessmentofriskof bias}

Any thorough systematic review needs to assess the methodological quality of the included studies. In systematic reviews, the main issue is whether the effect seen in the primarystudies is the true effect or whether a defect in study design (internal validity) has led the result to be over or under-estimated (biased). ${ }^{29}$

All included studies were assessed by two review authors (LE, DP) for possible risk of bias. For RCTs this was conducted as described in the Cochrane Handbook of Systematic Reviews of Interventions. ${ }^{30}$ The assessment included information about the design, conduct, and analysis of the trial.

For non-randomised trials no validated critical appraisal or risk of bias tool was available for use.$^{31-33}$ Therefore, the risk of bias was assessed using the domains defined by Sanderson et al ${ }^{31}$ as critical for the assessment of study quality of observational studies. Sanderson and colleagues developed a tool for assessing whether critical appraisal tools within their systematic review contained the ess ential information for appraising the conduct of observational studies based on the STROBE guidelines ${ }^{34}$ (Appendix 2).

Information from relevant reporting guidelines (CHERRIES, COREQ, STROBE) ${ }^{34-36}$ were used to aid the decision on whether an aspect of a particular study design would affect the internal val idity of the study. The types of bias were then rated within each category as high, low or unclear risk of bias. This system of reporting bias is obviously flawed and so the reasons why studies were categorised as low, high or unclear risk of bias were documented to enable readers to come to their own conclusions about the degree of bias inherent within each study and to aid transparency of the review process. ${ }^{29}$

Quality of life and bleeding 
Measures of treatment effect

When available we recorded dichotomous outcomes as the numbers of outcomes and continuous outcomes as means and standard deviations. No relative effect measures were calculated. Qualitative information was transcribed from the study report and quoted verbatim.

Dealing with missing data

Three of the four included study authors were contacted by e-mail in order to obtain information that was missing or unclear in the published reports. ${ }^{37-39}$ Two authors responded and provided further unpublished information. ${ }^{37,38}$ The author of one of the on-going studies confirmed that this has not yet been published in full. ${ }^{40}$

Two trials included patients with hematologic malignancies as well as patients with solid tumours or non-malignant hematologic disorders. The authors were contacted because data could not be extracted for a malignant hematology 'subgroup' from the reported information. In both studies, patients with hematologic malignancies constituted only a minority of all study patients and the authors were unable to provide additional information on the hematology sub-group, these studies were therefore excluded from the review. ${ }^{41,42}$

\section{Datasynthesis}

We provided a narrative synthesis of the findings from the included studies, structured around the type of study design and type of outcome. No meta-analyses were performed because the studies were not homogeneous in their study design.

No formal assessments of heterogeneity or reporting biases we re performed because no meta-analyses were performed.

Quality of life and bleeding 


\section{Results}

\section{Description of studies}

\section{Results of the search}

(See Figure 2-PRISMA Flow Diagram). 6247 studies were initially identified after duplicates were removed, 5945 studies were excluded on the basis of the abstract by one review author (LE, AK or DP) and $20 \%$ of these abstracts were randomly selected and independently assessed by a second review author (LE, AK or DP). 302 full text articles were assessed for eligibility by any two of four review authors (LE, AK, DP, ES).

\section{Included studies}

Study Type. There were six studies within seven citations eligible for inclusion within this review. One of these studies is due to start recruiting patients, ${ }^{43}$ and the other has not yet been published in full ${ }^{40}$ (Table S1 Appendix5). Of the completed studies, there was one RCT; ${ }^{39}$ one prospective observational study ${ }^{38}$ one interview study $;^{44}$ and one web-based survey ${ }^{37,45}$ (Table 1: Characteristics of Included Studies). In total four studies were included in this review.

Participants. The four included studies contained 450 participants. One study consisted of only patients with MDS, ${ }^{37}$ the other three studies consisted of patients with a mixture of diagnoses (Table 1). The mean age of patients within the studies ranged from 49 to 70 years of age.

Interventions. There was only one interventional study, ${ }^{39}$ and this was an RCT. This examined the effects of a computer-assisted, interactive tailored patient assessment (ITPA) tool on patient care, symptom distress, and patients' need for symptom management during treatment and rehabilitation.

Outcomes. None of the four studies were designed to study the effect of bleeding on HRQoLor IPs.

All of the studies reported overall symptom distress, disease burden or HRQoL related to their disease or its treatment as their main outcome measure.$^{37-39,44}$ Assessment of symptom distress or disease burden 
was assessed as a one-off measure in two studies..$^{37,44}$ It was assessed over 30 days in one study ${ }^{38}$ and for up to one year in the final study ${ }^{39}$ (Table 1).

\section{Excluded studies}

There were 295 studies excluded on the basis of a full text review (Appendix 3: Screening Algorithm). The reasons for exclusion were: no bleeding reported ( $n=204)$; no patient-related outcome reported ( $n=42)$; review rather than primary study $(n=29)$; retrospective study $(n=15)$; and wrong patient group (i.e. not patients with haematological malignancies or myelodysplasia) $(n=5)$. (For a list of excluded studies see Appendix 4).

\section{Risk of bias}

All included studies were assessed by two review authors (LE, DP) as previously described and all four studies were found to be at significant risk of bias (See Table 2 for the separate risk categories and reasons why each study was rated as high, low or unclear risk).

\section{Patient reported Outcome Measures (PROMS)}

Illness Perception (IPs) Questionnaires

No IP questionnaires were used to assess patients' IPs within any of the four studies.

\section{HRQoLQuestionnaires}

A wide number of established and novel tools were used to assess the patients' HRQoL within the four included studies (Table 1\& Appendix 5 Table S2). The number of HRQoL assessment tools used in each study varied between one ${ }^{39}$ and three..$^{37,38,44}$

The Functional Assessment Cancer Therapy (FACT) was the only tool used in more than one study. ${ }^{37,38}$ Other widely used and validated HRQoL tools within the studies included:SF-36; ${ }^{39}$ EORTCQLQ-C30;44 Profile of Mood States (POMS); ${ }^{38}$ and EuroQol EQ-5D. ${ }^{37}$

\section{Quality of life and bleeding}


Two of the studies used novel HRQoL tools which included specific questions relating to bleeding. ${ }^{37,38}$ (Table $1 \&$ Appendix 5Table S2).

Timing of HRQoL assessments. (Table 1) All studies completed a minimum of one HRQoLassessment, with the two cross-sectional studies only completing a single assessment. ${ }^{37,44}$

Other PROMS

The $\mathrm{RCT}^{39}$ used their novel interactive tailored patient assessment (ITPA) tool to assess symptom distress, and patients' need for symptom management prior to inpatient and outpatient assessments for up to 365 days.

Assessment of bleeding

(See Table 1)

Formalized bleeding assessments

None of the studies reported using a specific bleeding assessment tool. ${ }^{37-39,44}$

\section{Effects of interventions}

(See Table 3)

Primary Outcome: Health related Quality of life (HRQoL)/Illness Perception(IP) and its relation to bleeding

None of the studies reported a quantitative relationship between IP and bleeding or between HRQoL and bleeding. ${ }^{37-39,44}$

The RCT only reported a combined outcome measure of bleeding and infection as one of their symptom distress measures..$^{39}$ The authors were contacted for further information but did not respond. 
In the prospective observational study (autologous stem cell transplant patients) only $3 \%$ of patients had moderate or severe bleeding during the study. ${ }^{38}$ The authors did not analyse separately patients who bled and patients who did not bleed it was therefore not possible to assess whether bleeding caused symptom distress [unpublished information from authors].$^{38}$

The on-line survey of MDS patients assessed concern about bleeding but did not relate it to whether patients had experienced recent bleeding or not. ${ }^{37}$ Only $68.5 \%$ of patients $(137 / 200)$ answered this section of the survey, and only $20 \%$ of these patients (28/137) had a platelet count less than $50 \times 10^{9} / \mathrm{L}$ (Table 4). Significant differences in platelet count groups were obtained on worry about serious bleeding, pinpoint bleeding and vaginal bleeding, patients within the 30 to 49 platelet count group ( $7 \%$ of patients (9/137) reported the most problems [unpublished information provided by the author]. ${ }^{37}$ The 14\% (19/137) of patients with platelet counts below 30 reported far fewer concerns about bleeding. None of the platelet count groups showed differences in concern about bleeding from the mouth and gums, nose or seeing blood in the urine or stool.

In the interview study (leukemia and lymphoma patients), bleeding was only mentioned as part of the open-ended interview, no quantitative assessment was performed. ${ }^{44}$ Two of the five patients had nosebleeds (during the interview) ${ }^{44}$ and neither participant felt this was important. However, the interviewers noted that all the patients downplayed all their physical symptoms significantly despite objective evidence of significant weight loss, hair-loss, mucositis or bleeding.

\section{Secondary Outcome: Number and severityofbleeding episodes}

Three of the four studies reported bleeding ${ }^{37,38,44}$ (See Table 3). The prospective observational study reported bleeding at platelet count nadir in only $3 \%$ of patients. ${ }^{38}$ The interviewstudy reported epistaxis in two patients and bruising was noted by the interviewers but there was no comment about the severity of the bleeding. ${ }^{44}$ The on-line survey asked about bleeding present in the preceding week however the answers were poorlycompleted. Overall, only $55 \%$ of patients ( $76 / 137$ with a known 
platelet count) reported whether they had had spontaneous bleeding, bruising, blood blisters in the mouth or blood in the urine or stool within the previous week [unpublished data provided by the author] (Table 4). ${ }^{37}$

\section{Secondary Outcome: Mortality (All-cause or secondary to bleeding)}

This outcome was only relevant to two of the four studies ${ }^{38,39}$ (longitudinal studies). The other two studies were of a cross-sectional design and all patients had to be alive to participate in the studies. ${ }^{37,44}$ Of these two studies, only one study reported all-cause mortality. ${ }^{39} 11$ patients died in the intervention arm and eight patients died in the control arm during the first 100 days. Neither study reported mortality due to bleeding.

\section{Discussion}

The main objective of this review was to determine whether bleeding affects HRQoLor Illness Perception (IP) in patients with hematologic malignancies or myelodysplasia. Other objectives were to: determine whether a HRQoL tool had been developed that specifically assessed patient distress/concern in relation to bleeding symptoms; determine whether any studies had used interventions to re duce symptom distress; and assess the methodological quality of included studies.

\section{Summary of key findings}

Six studies were identified and two of these studies have not been completed. There were therefore four studies included in this review.

This review found no studies that evaluated the differences in HRQoL or IPs between patients who did or did not experience bleeding. Thus we are unable to establish the extent to which bleeding affects HRQoL or illness perceptions. Nor were we able to establish whether patients with myelodysplasia had a 
different perception of bleeding to those patients with transient bone marrow failure (e.g. after chemotherapy or stem cell transplantation).

The web-based survey ${ }^{37}$ and observational study ${ }^{38}$ used two new patient-reported outcome (PRO) scales FACT-Th (MDS patients) and MDASI-BMT (stem-cell transplant patients), respectively which specifically assessed patient distress/concern in relation to bleeding symptoms. However, these tools were not used within these studies to assess differences in HRQoL due to bleeding.

The RCT ${ }^{39}$ did use an ITPA tool to assess symptom distress and feed back information to the nurses and doctors but they did not analyse bleeding separately from infection and the refore effectiveness of this tool for reducing symptom distress due to bleeding is unknown.

\section{Quality of the evidence}

Overall the quality of the evidence is poor. The four studies identified in the systematic review were all at a significant risk of bias.

There is no universal validated and well used patient reported outcome measure which could be used to assess the impact of bleeding on quality of life in patients with hae matological mal ignancies and MDS. The two HRQoL tools which included an assessment of bleeding (MDASI-BMT and FACT-Th) have not been validated in this patient group. Furthermore the remaining HRQoL tools used in these studies were not designed to assess the impact of bleeding upon HRQoL (Table S2 Appendix 5).

In addition the two studies that assessed patient reported outcome measures to evaluate HRQoL prospectively over time, were undertaken over very different time periods. Both studies reported high attrition rates and losses to follow-up. ${ }^{38,39}$ The remaining two studies only performed a single assessment (Table 1). HRQoLassessments are more likely to provide meaningful information to healthcare professionals when they are reported sequentially to provide a representation of changes overtime..$^{46,47}$

\section{Quality of life and bleeding}


Patients with hematologic malignancies and MDS often have many other symptoms including side effects of complex and variable treatments, in addition to the psychological impact of fear, insecurity and carer/hospital dependence; all of which are important to patients. Indeed, within the four identified studies patients often rated symptoms other than bleeding as more problematic. However, whether this is due to the underlying study design; in that investigators failed to acknowledge the potential impact of bleeding through direct patient questioning or whether other symptoms are more concerning to patients is unclear. Certainly, the incidence of bleeding (3\%) was much lower in the prospective observational study ${ }^{38}$ than rates seen in recent well-conducted platelet transfusion trials of similar patients ( 45 to $59 \%$ ). ${ }^{5,48}$ In these platelet transfusion studies formalized daily bleeding assessments were performed and the rates of severe or life-threatening bleeding were similar to the overall incidence of bleeding ( 2 to $9 \%$ ) reported in the cohort study. ${ }^{38}$

\section{Strengths and Limitations}

We know of no previous reviews on this subject and within this review found four low quality studies that were not specifically designed to answer the question posed by this systematic review. There were no obvious biases within the review process: a protocol was pre-specified, a wide search was conducted, the relevance of each paper identified was carefullyassessed, and no restrictions were made for the language in which the paper was originally published.

Excluding studies that only reported bleeding as an adverse event did not limit this review's findings. Any study that only reported bleeding as an adverse event would not separate patients with bleeding and those who did not in to two separate groups and compare patient reported outcome measures between the two groups.

Quality of life and bleeding 
Limiting this reviewto only patients with hematologic malignancies or MDS may have limited the generalizability of this review to patients with other types of cancer. However, patients with hematologic disorders have more profound and prolonged thrombocytopenia than patients with other types of cancer. This is reflected by the fact that hematology patients use up to $60 \%$ of all platelet transfusions issued. ${ }^{49}$ We chose to limit our review to patients with hematologic malignancies or MDS because if there is a true difference in symptom distress or HRQoL due to bleeding it is more likely to be detected within this high risk patient group.

It is important to distinguish between qual ity of reporting and quality of what was actually done in the design, conduct and analysis of a study. A high quality report ensures that all relevant information is available to the reader but does not guarantee it is free of bias..$^{50}$

The assessment of methodological quality and risk of bias was limited by the lack of a 'gold-standard' critical appraisal tool (CAT). Several systematic reviews have assessed tools for assessing quality and susceptibility to bias in non-randomised studies. ${ }^{31-33}$ All these reviews have concluded that there is no currently agreed 'gold standard' critical appraisal tool; the majority of tools did not undergo a rigorous development process and that there are many tools to choose from. Katrak and colleagues ${ }^{32}$ identified 121 critical appraisal tools and Sanderson and colleagues identified 86 tools. ${ }^{31}$ Quality scales and resulting scores tend to combine aspects of reporting quality and aspects of trial quality which can lead to a flawed assessment, and therefore these types of assessments should be avoided. ${ }^{51,52}$

Due to these problems we tried to make our risk of bias assessment as transparent as possible. We used categories that had been previously recognised as critically important for assessing methodological quality, ${ }^{31}$ provided the reasons we classified a study as at high, unclear, or low risk of bias as well as our summary decision for each domain.

Quality of life and bleeding 


\section{Implications for Practice and Research}

There is a lack of evidence to establish if bleeding is a significant clinical problem that affects patients' HRQoL or illness perceptions. The four studies identified in the systematic review did not foc us primarily on bleeding. This review will therefore not affect current clinical practice because we found no evidence on which to base a change in practice.

The main implications of this revieware the research agenda, as well as awaiting the results of the two on-going studies in patients with MDS (Table S1 Appendix 5). Studies are required to assess whether bleeding causes patients distress, and if so, to what extent this occurs and whether this differs between patients with prolonged periods of thrombocytopenia e.g. MDS or patients with reversible thrombocytopenia (e.g. after chemotherapy or a stem cell transplant). Different research approaches may be required, including the development of a validated patient-reported outcome measure, as well as independently verified documentation of the presence or absence of bleeding.

\section{Contributions of authors}

Lise Estcourt: protocol development, searching, selection of studies, eligibility and quality assessment, data analysis and content expert.

Debbie Pinchon: protocol development, searching, selection of studies, eligi bility and quality assessment, data extraction and analysis and content expert.

Emily Symington: selection of studies, eligi bility and quality assessment, data extraction and analysis. Anne Kelly: protocol development, selection of studies, eligibility assessment.

Susan Brunskill: protocol development and methodological expert.

Carolyn Doree: protocol development, searching and selection of studies.

Liz Glidewell: protocol development and content expert.

Simon Stanworth: protocol development and content expert.

Quality of life and bleeding 
Lise Estcourt drafted the paper and all review authors contributed to the preparation of the final review article.

\section{Conflicts of interest}

None known

\section{Funding}

NHS Blood and Transplant via the Systematic Review Initiative

\section{Acknowledgements}

We thank Mr JA Bunola, Consultant Orthopaedic Surgeon, Hull and East Yorkshire NHS Trust; Dr Martin Besser, Consultant Haematologist, Cambridge University Hospitals NHS Foundation Trust; Mr Jean Christophe Bodhuin; and Mrs Ruth Strachan for their assistance in translating foreign language articles. We thank the authors who provided further unpublished information for their kind cooperation: Karen Anderson, M. D. Anderson Cancer Center; Benjamin Arnold, FACIT organis ation; James Twiss, Galen Research; and the MDS Foundation.

Quality of life and bleeding 


\section{Figure I: Leventhal's Common Sense Model of Illness Representation}

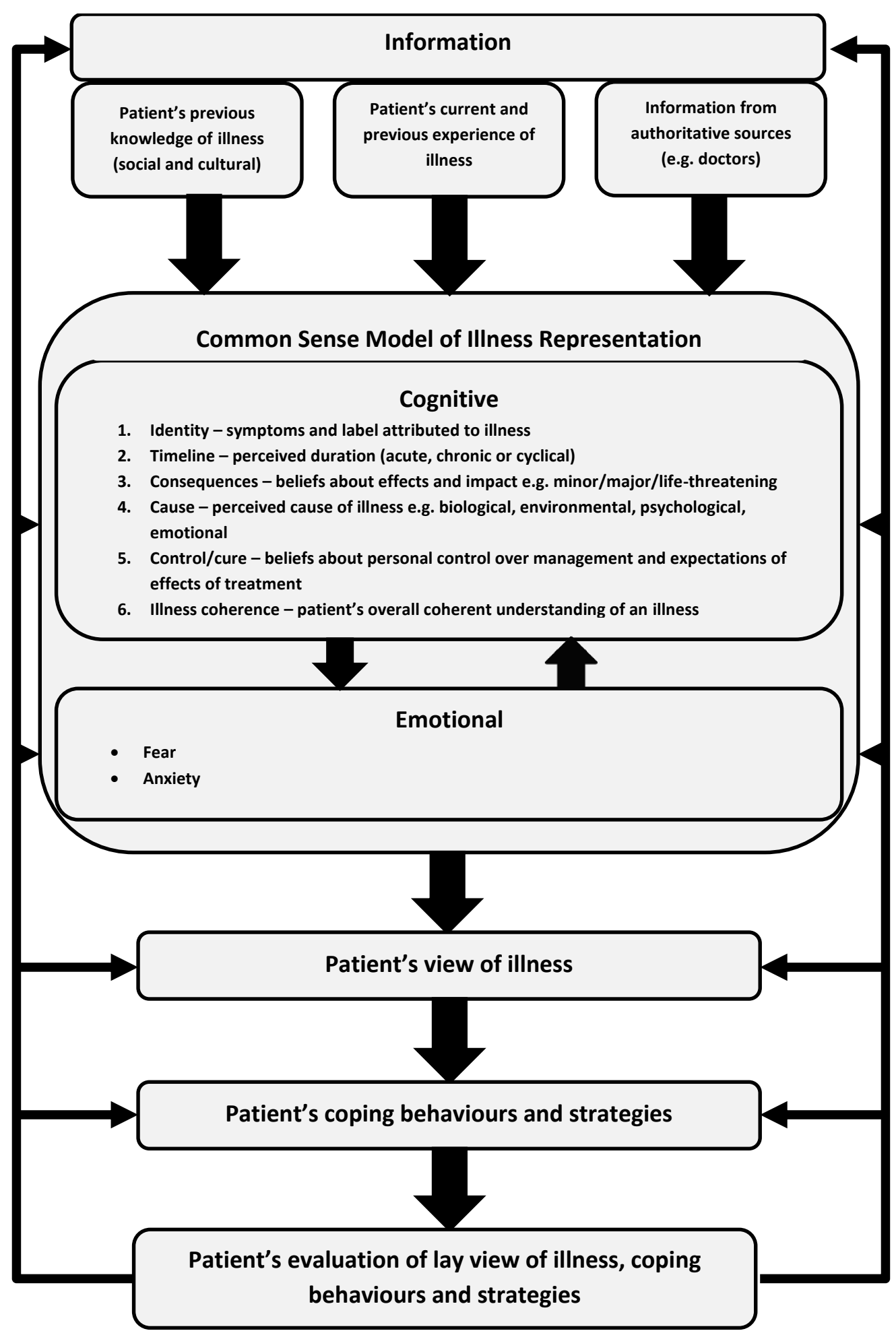




\section{Figure 2: PRISMA Flow Diagram}

\section{PRISMA Flow Diagram}
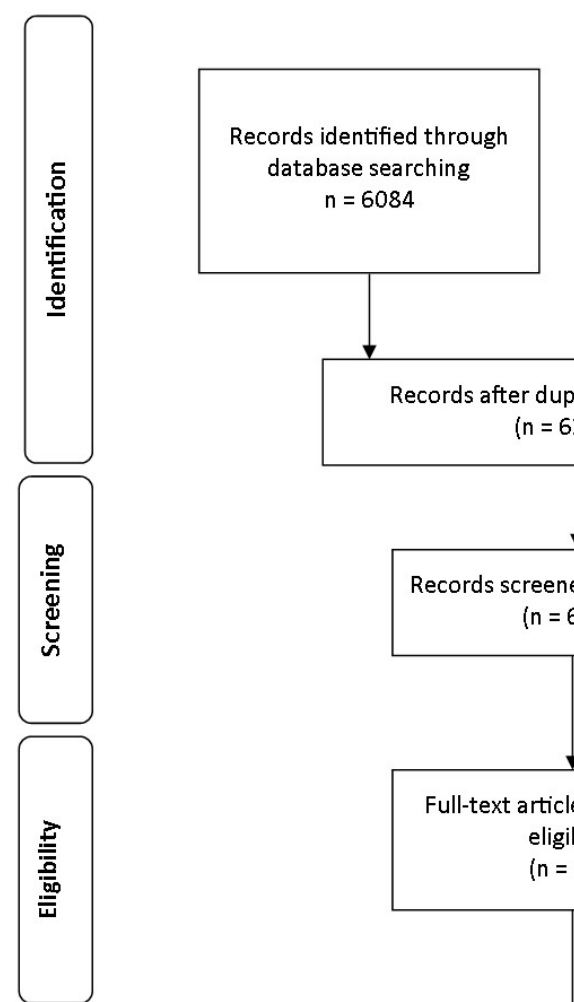

Additional records identified through other sources (Hand-searching and clinical trials registries) $(\mathrm{n}=5)$

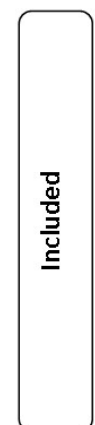
$(\mathrm{n}=2)$

$$
\begin{gathered}
\text { Studies included in narrative re- } \\
\text { view } \\
\text { (n=4 within } 5 \text { citations) } \\
\begin{array}{c}
\text { Studies included in quantitative } \\
\text { synthesis (meta-analysis) } \\
(n=0)
\end{array}
\end{gathered}
$$

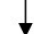


Table I Characteristics of included Studies

\begin{tabular}{|c|c|c|c|c|c|c|c|}
\hline Study \& country & Study design & No. of participants & Main aim of study & $\begin{array}{l}\text { Assessment of patient- } \\
\text { related outcomes }\end{array}$ & Assessment of bleeding & $\begin{array}{l}\text { Haematological diagnosis } \\
\text { and treatment of } \\
\text { participants }\end{array}$ & $\begin{array}{c}\text { Mean age } \\
\text { participants } \\
\text { (yrs) }\end{array}$ \\
\hline $\begin{array}{l}\text { Ruland 2010 } \\
\text { Norway }\end{array}$ & $\begin{array}{l}\text { RCT } \\
\text { Multi-centre }\end{array}$ & $\begin{array}{c}145 \\
\text { (75 intervention } \\
70 \text { control) } \\
100 \text { followed up for } 100 \\
\text { days } \\
{[19(13 \%) \text { died, } 10(7 \%)} \\
\text { dropped out, } 16(11 \%) \\
\text { lost to follow-up] } \\
51 \text { followed up for } 365 \\
\text { days }\end{array}$ & $\begin{array}{l}\text { Does us e of a novel ITPA } \\
\text { reduce symptom burden }\end{array}$ & $\begin{array}{l}\text { SF-36 } \\
\text { (baseline only) } \\
\text { ITPA* } \\
\text { (Prior to inpatient and } \\
\text { outpatient assessments } \\
\text { for up to } 365 \text { days) }\end{array}$ & $\begin{array}{l}\text { Self-reported using ITPA } \\
\text { and retrospective review } \\
\text { of the notes to confirm } \\
\text { symptoms reported by } \\
\text { patient. }\end{array}$ & $\begin{array}{l}\text { Leukaemia (28) } \\
\text { Lymphoma (111) } \\
\text { Myeloma (6) } \\
\text { Chemotherapy (98) } \\
\text { SCT (47) }\end{array}$ & 49.5 \\
\hline $\begin{array}{l}\text { Anderson } 2007{ }^{38} \\
\text { USA }\end{array}$ & $\begin{array}{l}\text { Prospective } \\
\text { observational study } \\
\text { Single centre }\end{array}$ & $\begin{array}{c}100 \\
12 \text { lost to follow-up } \\
(12 \%)\end{array}$ & $\begin{array}{l}\text { Assess symptom burden } \\
\text { of patients undergoing } \\
\text { autologous stem cell } \\
\text { transplant }\end{array}$ & $\begin{array}{l}\text { MDASI-BMT* } \\
\text { (5x baseline to D30) } \\
\text { FACT-BMT (Baseline \& } \\
\text { D30) } \\
\text { POMS (Baseline \& D30) }\end{array}$ & Method not reported & $\begin{array}{l}\text { Non-Hodgkins lymphoma (34) } \\
\text { Myeloma (66) } \\
\text { SCT (100) }\end{array}$ & 53.6 \\
\hline $\begin{array}{l}\text { Persson 1995 } \\
\text { Sweden }\end{array}$ & $\begin{array}{l}\text { Open-ended interview } \\
\text { Single centre }\end{array}$ & 5 & $\begin{array}{l}\text { Explore patients } \\
\text { experience of physical }\end{array}$ & $\begin{array}{l}\text { Open-ended interview. } \\
\text { EORTC QLQ-C30 }\end{array}$ & $\begin{array}{l}\text { Noted by interviewer. No } \\
\text { systematic a ssessment of }\end{array}$ & $\begin{array}{l}\text { Acute leukaemia (4) } \\
\text { Lymphoma (1) }\end{array}$ & 70.4 \\
\hline
\end{tabular}

Quality of life and bleeding 


\begin{tabular}{|c|c|c|c|c|c|c|c|}
\hline & & & $\begin{array}{l}\text { and psychological } \\
\text { problems during active } \\
\text { phase of disease and } \\
\text { treatment }\end{array}$ & $\begin{array}{l}\text { SOC } \\
\text { LGC } \\
\text { (Single assessment) }\end{array}$ & bleeding & $\begin{array}{l}\text { Active treatment (5), type of } \\
\text { treatment not reported }\end{array}$ & \\
\hline $\begin{array}{l}\text { List } \mathbf{2 0 0 9}^{37} \\
\text { USA }\end{array}$ & $\begin{array}{c}\text { Web-based survey } \\
\text { Multi-centre }\end{array}$ & $\begin{array}{l}\text { 200 } \\
137 \text { included in a nalysis } \\
\text { of bleeding and platelet } \\
\text { count }^{+}\end{array}$ & $\begin{array}{l}\text { Explore the patient } \\
\text { burden associated with } \\
\text { MDS disease and } \\
\text { treatment }\end{array}$ & $\begin{array}{l}\text { Bespoke measure* } \\
\text { includedt } \\
\text { EQ-5D } \\
\text { FACT-Th } \\
\text { FACT-G } \\
\text { Other items from } \\
\text { questionnaires used in } \\
\text { clinical studies MDS } \\
\text { (Single assessment) }\end{array}$ & Self-reported & $\begin{array}{l}\text { MDS } \\
\text { Only } 28 \text { had platelet count < } \\
50 \times 10^{9} / \mathrm{L}^{+} \\
\text {Chemotherapy }(39 / 70)^{* *+}\end{array}$ & 64.7 \\
\hline
\end{tabular}

*Patient related outcome measure devised for this study

tUnpublisheddata

** Only 70 of the 200 study patients reported whether or not they were currently receiving any chemotherapy trea tment

EORTC $=$ European Organization for Research and Treatment of Cancer; FACT-BMT $=$ Functional ass essment of Cancer Therapy - Bone Marrow Transplantation; FACT-G = Functional assessment of

Cancer Therapy -General; FACT- Th = Functional assessment of Cancer Therapy - Thrombocytopenia; IPSS = Intemational Prognostic Scoring System; ITPA = Interactive Tailored Patient Assessment;

LGC = Lund Gerontology Centre; MDASI-BMT = MD Anderson Symptom Inventory- Bone Marrow Transplant; POMS = Profile of Mood States; SCT=Stem cell trans plant; SF-36= Short Form 36; SOC = Sense of Coherence Scales

\section{Quality of life and bleeding}


Table 2: Risk of Bias Table

\begin{tabular}{|c|c|c|c|c|}
\hline Study Name & Ruland $2010^{39}$ & Anderson $2007^{38}$ & Persson 19944 & List $2009^{37}$ \\
\hline Type of Study & RCT & $\begin{array}{l}\text { Prospective observational cohort } \\
\text { study }\end{array}$ & Interview study & On-line survey \\
\hline Selection bias & $\begin{array}{l}\text { Low RIsk } \\
\text { Adequate sequence generation } \\
\text { Computer-generated minimisation } \\
\text { algorithm that equalised groups on gender } \\
\text { and type of treatment. } \\
\text { Allocation concealment } \\
\text { Tablet computer was programmed so that } \\
\text { the randomization algorithm could only be } \\
\text { accessed after completion of baseline } \\
\text { assessment }\end{array}$ & $\begin{array}{l}\text { Unclear RIsk } \\
\text { Appropriate source population } \\
100 \text { of } 148 \text { eligible patients approached } \\
\text { agreed to participate but did not describe } \\
\text { how it was decided which patients should } \\
\text { be approached. }\end{array}$ & $\begin{array}{l}\text { Unclear Risk } \\
\text { Appropriate source population } \\
\text { "A consecutive sample of five patients" } \\
\text { with acute leuka emia or a high grade } \\
\text { lymphoma. Did not describe whether they } \\
\text { were consecutive admissions, or in what } \\
\text { way they were consecutive. }\end{array}$ & $\begin{array}{l}\text { High Risk } \\
\text { Appropriate source population } \\
\text { Selected group of patients. Invited into } \\
\text { study on attendance at MDS Foundation } \\
\text { forum, or via internet }\end{array}$ \\
\hline $\begin{array}{l}\text { Performance } \\
\text { bias }\end{array}$ & $\begin{array}{l}\text { High Risk } \\
\text { Blinding of clinician and patient } \\
\text { Due to nature of study the patient's group } \\
\text { assignment could not be concealed after } \\
\text { baseline data were obtained as it was to }\end{array}$ & $\begin{array}{l}\text { Unclear Risk } \\
\text { Appropriate methods to deal with any } \\
\text { design-specific issues } \\
\text { Self-report by patient, however research } \\
\text { nurses had provided education. Not enough }\end{array}$ & $\begin{array}{l}\text { Unclear Risk } \\
\text { Appropriate methods to deal with any } \\
\text { design-specific issues } \\
\text { No information on: who conducted } \\
\text { interview; whether a relationship was }\end{array}$ & $\begin{array}{l}\text { High Risk } \\
\text { Appropriate methods to deal with any } \\
\text { design-specific issues } \\
\text { Self-report by patient }\end{array}$ \\
\hline
\end{tabular}

Quality of life and bleeding 


\begin{tabular}{|c|c|c|c|c|}
\hline & $\begin{array}{l}\text { provide nurses and physicians with } \\
\text { assessment summaries of patient } \\
\text { symptoms, problems, and concems }\end{array}$ & $\begin{array}{l}\text { detail provided on education regarding } \\
\text { completion of forms. }\end{array}$ & $\begin{array}{l}\text { established between the interviewer and } \\
\text { patient prior to study commencement; } \\
\text { whether the setting for the interview was } \\
\text { appropriate; whether interviewer may be } \\
\text { biased. }\end{array}$ & \\
\hline Detection bias & $\begin{array}{l}\text { Low RIsk } \\
\text { Blinding of outcome assessor } \\
\text { To compare groups, two trained raters } \\
\text { who were blinded to patients' study group } \\
\text { assignment conducted independent chart } \\
\text { audits for inpatient and outpatient visits } \\
\text { and abstracted both physicians' and } \\
\text { nurses' inpatient and outpatient notes for } \\
\text { symptoms, problems and concerns } \\
\text { equivalent tothose contained in the } \\
\text { Choice ITPA. }\end{array}$ & $\begin{array}{l}\text { High Risk } \\
\text { Blinding of outcome assessor } \\
\text { Only ECOG PS (Eastern Co-operative } \\
\text { Oncology Group Performance Status) was } \\
\text { used to assess the health care provider's } \\
\text { estimate of patient's functional status at } \\
\text { each time point. Laboratory variables that } \\
\text { might affect patient's symptoms were also } \\
\text { recorded. No independent blind asses sment } \\
\text { of outcome reported. }\end{array}$ & $\begin{array}{l}\text { High Risk } \\
\text { Patients minimised their physical } \\
\text { problems. Weight loss evident in all } \\
\text { patients, but only one sawit as a } \\
\text { problem. Severe oral complications noted } \\
\text { by interviewer, but patients did not talk } \\
\text { about them much. No independent report } \\
\text { by nurse or family member. }\end{array}$ & Self-report by patient. \\
\hline $\begin{array}{l}\text { Incomplete } \\
\text { outcome data } \\
\text { (attrition bias) }\end{array}$ & $\begin{array}{l}\text { High Risk } \\
\text { Authors mentioned attrition rates, only } 51 \\
\text { patients were followed up for } 1 \text { year. The } \\
\text { planned duration of the study. }\end{array}$ & $\begin{array}{l}\text { High Risk } \\
3 \text { patients lost to follow up before blood } \\
\text { count nadir. } 9 \text { patients lost by the time of } \\
\text { last assessment at } 30 \text { days (Missing data }\end{array}$ & $\begin{array}{l}\text { Unclear Risk } \\
\text { No discussion of possibility of saturation } \\
\text { of data }\end{array}$ & $\begin{array}{l}\text { High Risk } \\
200 \text { patients participated in on-line } \\
\text { study. Only } 137 \text { completed section on } \\
\text { bleeding and platelet count* }\end{array}$ \\
\hline
\end{tabular}

\section{Quality of life and bleeding}




\begin{tabular}{|c|c|c|c|c|}
\hline & & $\begin{array}{l}\text { replaced bylast observation carried } \\
\text { forward) }\end{array}$ & & \\
\hline $\begin{array}{l}\text { Selective } \\
\text { reporting } \\
\text { (reporting } \\
\text { bias) }\end{array}$ & $\begin{array}{l}\text { High Risk } \\
\text { Bleeding and infection assessed under } \\
\text { single sub-group of symptom distress }\end{array}$ & $\begin{array}{l}\text { High Risk } \\
\text { FACT-BMT P-values only reported in study } \\
\text { for baseline against symptoms of fatigue, } \\
\text { sleep disturbance, lack of appetite and pain }\end{array}$ & $\begin{array}{l}\text { Low RIsk } \\
\text { Tape-recorded interview transcribed } \\
\text { verbatimand 'analysed from a } \\
\text { hermeneutic phenomenological } \\
\text { perspective'. Independently asses sed by } 2 \\
\text { authors. Quotations provided and } \\
\text { organised intothemes:' physical } \\
\text { problems; psychosocial problems; } \\
\text { patients' coping strategies...; patients' } \\
\text { opinions of the care provided'. } \\
\text { 'Methodological triangulation was } \\
\text { applied'. }\end{array}$ & $\begin{array}{l}\text { Low RIsk } \\
\text { Unpublished data from MDS foundation } \\
\text { provided* }\end{array}$ \\
\hline $\begin{array}{l}\text { Other bias } \\
\text { (including } \\
\text { funding) }\end{array}$ & $\begin{array}{l}\text { Low RIsk } \\
\text { No other sources of bias identified }\end{array}$ & $\begin{array}{l}\text { Low RIsk } \\
\text { No other sources of bias identified }\end{array}$ & $\begin{array}{l}\text { Low RIsk } \\
\text { No other sources of bias identified }\end{array}$ & $\begin{array}{l}\text { Low RIsk } \\
\text { No other sources of bias identified }\end{array}$ \\
\hline $\begin{array}{l}\text { Protocol } \\
\text { deviation }\end{array}$ & Unclear Risk & Unclear Risk & Unclear Risk & Unclear Risk \\
\hline
\end{tabular}

Quality of life and bleeding 


$\begin{array}{ll}\text { No protocol available } & \text { No protocol available } \\ \text { * = unpublished data } & \text { No protocol available }\end{array}$

$\mathrm{NA}=$ type of bias not applicable to study design 
Table 3: Primary and secondary outcomes of the review

\begin{tabular}{|c|c|c|c|c|}
\hline \multirow[t]{2}{*}{ Study } & \multirow{2}{*}{$\begin{array}{c}\text { Primary Outcome } \\
\text { Quality of life/illness perception and } \\
\text { its relation to bleeding }\end{array}$} & \multicolumn{2}{|c|}{ Secondary Outcomes } & \multirow[t]{2}{*}{ Comment } \\
\hline & & $\begin{array}{l}\text { Number and severity of bleeding } \\
\text { episodes }\end{array}$ & $\begin{array}{l}\text { All-cause mortality and mortality } \\
\text { secondary to bleeding }\end{array}$ & \\
\hline Ruland $2010^{39}$ & $\mathrm{NR}$ & $\mathrm{NR}$ & $\begin{array}{l}19 \text { died during first } 100 \text { days. } \\
11 \text { intervention group } \\
8 \text { control group } \\
\text { Mortalitydue to bleeding not } \\
\text { reported }\end{array}$ & $\begin{array}{l}\text { Bleeding and infection assessed } \\
\text { under single sub-group of symptom } \\
\text { distress }\end{array}$ \\
\hline Anderson $2007^{38}$ & NR & $\begin{array}{c}\text { Percentage of patients with } \\
\text { moderate or severe bleeding } \\
0 \% \text { baseline } \\
3 \% \text { count nadir } \\
1 \% \text { day } 30\end{array}$ & NR & $\begin{array}{c}\text { MDASI-BMT mean symptom score } \\
\text { bleeding } \\
0.14(0.62 \mathrm{SD}) \text { baseline } \\
0.31(1.20 \mathrm{SD}) \text { count nadir } \\
0.15(0.89 \mathrm{SD}) \text { day } 30\end{array}$ \\
\hline Persson $1995^{44}$ & $\begin{array}{l}2 \text { patients who had e pistaxis during } \\
\text { interview did not consider it } \\
\text { important }\end{array}$ & $\begin{array}{l}2 \text { patients experienced epistaxis } \\
\text { during interview. Interviewer noted } \\
\text { bruising. Severity of bleeding was not } \\
\text { reported }\end{array}$ & NA & \\
\hline List 2009 & $\mathrm{NR}$ & $\begin{array}{l}\text { Self-reported bleeding in week prior } \\
\text { to survey. (Table 4) }\end{array}$ & NA & $\begin{array}{l}\text { Significant differences in platelet } \\
\text { count groups were obtained on } \\
\text { worry about serious bleeding, } \\
\text { pinpoint bleeding and vaginal }\end{array}$ \\
\hline
\end{tabular}

Quality of life and bleeding 


\begin{tabular}{|l|l|l|l|c|}
\hline & & & bleeding, 30-49 platelet count group \\
$(9$ patients) reporting most \\
problems*
\end{tabular}

$\mathrm{NR}=$ not reported $; \mathrm{NA}=$ not a pplicable

\section{Quality of life and bleeding}


Table 4: Bleeding present during preceding week within List $2009^{37}$ [unpublished data]

\begin{tabular}{|l|c|c|c|c|c|}
\hline & Platelet count <30 & Platelet count 30 to 49 & Platelet count 50 to 99 & Platelet count > 100 & Total \\
\hline $\begin{array}{l}\text { Presence or absence of } \\
\text { bleeding reported }\end{array}$ & $18 / 19(94.7 \%)$ & $7 / 9(77.8 \%)$ & $9 / 23(39.1 \%)$ & $42 / 86(48.8 \%)$ & 137 \\
\hline Spontaneous bleeding & $4 / 18(22.2 \%)$ & $3 / 7(42.9 \%)$ & $0 / 9(0 \%)$ & $2 / 42(4.8 \%)$ & 76 \\
\hline Bruises & $11 / 18(61.1 \%)$ & $6 / 7(85.7 \%)$ & $3 / 9(33.3 \%)$ & $14 / 42(33.3 \%)$ & 76 \\
\hline Blood blisters in mouth & $1 / 18(5.6 \%)$ & $1 / 7(14.3 \%)$ & $0 / 9(0 \%)$ & $4 / 42(9.5 \%)$ & 76 \\
\hline Blood in urine & $0 / 18(0 \%)$ & $0 / 7(0 \%)$ & $0 / 9(0 \%)$ & $0 / 42(0 \%)$ & $2 / 42(4.8 \%)$ \\
\hline Blood in stool & $3 / 18(16.7 \%)$ & $1 / 7(14.3 \%)$ & $2 / 9(22.2 \%)$ & & 76 \\
\hline
\end{tabular}

Quality of life and bleeding 


\section{References}

1. Cella DF. Quality of life: Concepts and definition. J Pain Symptom Manage. 1994;9(3):186-192.

2. Estcourt L, Birchall J, Lowe D, Grant-Casey J, Rowley M, Murphy MF. Platelet transfusions in haematology patients: are we using them appropriately? VoxSang. Nov 2012;103(4):284-293.

3. BCSH. British Committee for Standards in Haematology: Guidelines for the use of platelet transfusions. BrJ Haematol. Jul 2003;122(1):10-23.

4. Wandt $\mathrm{H}$, Schaefer-Eckart $\mathrm{K}$, Wendelin $\mathrm{K}$, et al. Therapeutic platelet transfusion versus routine prophylactic transfusion in patients with haematological malignancies: an open-label, multicentre, randomised study. Lancet. Aug 62012;380(9850):1309-1316.

5. Stanworth SJ, Estcourt $\amalg$, Powter G, et al. The effect of a no-prophylactic versus prophylactic platelet transfusion strategy on bleeding in patients with hematological malignancies and severe thrombocytopenia (TOPPS trial). A randomized controlled, non-inferiority trial. Blood. 2012;120:Abstract 1.

6. Saleh MN, Bussel JB, Cheng G, et al. Safety and efficacy of eltrombopag for treatment of chronic immune thrombocytopenia: results of the long-term, open-label EXTEND study. Blood. January 17, 2013 2013;121(3):537-545.

7. Cheng G, Saleh MN, Marcher C, et al. Eltrombopag for management of chronicimmune thrombocytopenia (RAISE): a 6-month, randomised, phase 3 study. The Lancet. //29 2011;377(9763):393-402.

8. Fogarty PF, Tarantino MD, Brainsky A, Signorovitch J, Grotzinger KM. Selective val idation of the WHO Bleeding Scale in patients with chronic immune thrombocytopenia. Current Medical Research and Opinion. 2012;28(1):79-87.

Quality of life and bleeding 
9. ButlerC, Doree C, Estcourt L, et al. Pathogen-reduced platelets for the prevention of bleeding (protocol). Cochrane Database Syst Rev. 2011;2011(4).

10. Estcourt L, Stanworth S, Doree C, et al. Prophylactic platelet transfusion for prevention of bleeding in patients with haematological disorders after chemotherapy and stem cell transplantation. Cochrane database of systematic reviews (Online). 2012 May 2012(5):CD004269.

11. Heddle NM, Arnold DM, Webert KE. Time to rethink clinically important outcomes in platelet transfusion trials. Transfusion. 2011;51(2):430-434.

12. Webert KE, Arnold DM, Lui Y, Carruthers J, Arnold E, Heddle NM. A new tool to assess bleeding severity in patients with chemotherapy-induced thrombocytopenia. Transfusion. Apr 9 2012;52(11):2466-2474.

13. Rebulla P, Finazzi G, Marangoni F, et al. The threshold for prophylactic platelet transfusions in adults with acute myeloid leukemia. Gruppo Italiano Malattie Ematologiche Maligne dell'Adul to. N EnglJ Med. Dec 25 1997;337(26):1870-1875.

14. Tinmouth A, Kotchetkova N, Tomlinson G, et al. A randomised phase II trial of low dose and standard dose platelet transfusions during induction therapy for acute leukemia or autologous stem cell transplantation. Vox Sang. 2002;83(Supplement 1):8.

15. Estcourt $\sqcup$, Heddle $N$, Kaufman R, et al. The challenges of measuring bleeding outcomes in clinical trials of platelet transfusions. Transfusion. Jan 2013:[E-Pub ahead of print].

16. Centers for Disease Control and Prevention (CDC). Health-Related Qual ity of Life. http://www.cdc.gov/hrqol/. Accessed November 8th, 2012.

17. FarnikM, Pierzchala WA. Instrument development and evaluation for patient-related outcomes assessments. Patient Relat Outcome Meas. Jul 2012;3:1-7. 
18. Rand Health. Medical Outcomes Study:36-Item Short Form Survey. http://www.rand.org/health/surveys tools/mos/mos core 36item.html. Accessed November 8th, 2012.

19. Functional Assessment of Chronic Illness Therapy (FACIT). Functional Assessment of Cancer Therapy - Bone Marrow Transplantation (FACT - BMT). 2007; http://www.facit.org/FACITOrg/Questionnaires. Accessed November 8th, 2012.

20. Leventhal H. Findings and theory in the study of fear communications. Advances in Experimental Social Psychology. 1970;5:119-186.

21. Leventhal H, Meyer D, Nerenz DR. The common sense representation of illness danger. In: Rachman S, ed. Medical Psychology. Vol II1980:7-30.

22. Leventhal $H$, Diefenbach MA, Leventhal EA. Illness cognition: using common sense to understand treatment adeherence and affect cognition interactions. Cognitive Therapy and Research. 1992;16:143-163.

23. Hagger MS, Orbell S. A meta-analytic review of the common-sense model of illness representations. Psychology \& Health. 2003;18(2):141-184.

24. Lau RR, Hartman KA. Common sense representations of common illnesses. Health Psychol. $1983 ; 5: 119-186$.

25. Weinman J, Petrie KJ, Moss-Morris R, Horne R. The Illness Perception Questionnaire: A new method for assessing the cognitive representation of illness. Psychology and Health. 1996;11:431-445.

26. Moss-Morris R, Weinman J, Petrie KJ, Horne R, Cameron LD, Buick D. The revised illness perception questionnaire (IPQ-R). Psychology and Health. 2002;17:1-16.

27. Mc Sharry J, Moss-Morris R, Kendrick T. Illness perceptions and glycaemic control in diabetes: a systematic review with meta-analysis. Diabet Med. Nov 2011;28(11):1300-1310. 
28. Higgins JP, Deeks JJ. Selecting studies and collecting data. In: Higgins JP, Green S, eds. Cochrane Handbookfor Systematic Reviews of Interventions. version 5.1.0 ed: Cochrane Collaboration; 2011.

29. Higgins JPT, Altman DG, Gøtzsche PC, et al. The Cochrane Collaboration's tool for assessing risk of bias in randomised trials. BMJ. 2011-10-18 00:00:00 2011;343.

30. Sterne J, Egger M, Moher D. Addressing reporting biases. In: Higgins J, Green S, eds. Cochrane Hand bookfor Systematic Reviews of Interventions. Version 5.1.0 ed: Cochrane Collaboration; 2011.

31. Sanderson S, Tatt ID, Higgins JP. Tools for assessing quality and susceptibility to bias in observational studies in epidemiology: a systematic review and annotated bibliography. IntJ Epidemiol. Jun 2007;36(3):666-676.

32. Katrak P, Bialocerkowski AE, Massy-Westropp N, Kumar S, Grimmer KA. A systematic review of the content of critical appraisal tools. BMCMed Res Methodol. Sep 16 2004;4:22.

33. Crowe M, Sheppard L. A review of critical appraisal tools show they lack rigor: Alternative tool structure is proposed. J Clin Epidemiol. 2011;64(1):79-89.

34. von Elm E, Altman DG, Egger M, Pocock SJ, Gotzsche PC, Vandenbroucke JP. The Strengthening the Reporting of Observational Studies in Epidemiology (STROBE) statement: guidelines for reporting observational studies. PLoS medicine. Oct 16 2007;4(10):e296.

35. Eysenbech G. Improving the quality of web surveys:the checklist for reporting results of intern et e-surveys (CHERRIES). Journal of MedicalInternet Research. 2004;6(3):e34. Accessed June 24 2012.

36. Tong A, Sainsbury P, Craig J. Consolidated criteria for reporting qual itative research (COREQ): a 32-item checklist for interviews and focus groups. Int J Qual Health Care. Dec 2007;19(6):349357. 
37. List AF, Mathias S, Crosby RD, Heptinstall K, Cella D. Disease Burden and Treatment Impact Associated with Myelodysplastic Syndromes: Preliminary Findings From a Web-Based Survey. ASH AnnualMeeting Abstracts. November 20, 2009 2009;114(22):4522-.

38. Anderson KO, Giralt SA, Mendoza TR, et al. Symptom burden in patients undergoing autologous stem-cell transplantation. Bone Marrow Transplant. 2007;39(12):759-766.

39. Ruland $\mathrm{C}$, Holte $\mathrm{H}$, Roislien J, et al. Effects of a computer-supported interactive tailored patient assessment tool on patient care, symptom distress, and patients' need for symptom management support: a randomized clinical trial. Journal of the American Medical Informatics Association. 2010;17(4):403-410.

40. McKennaSP, Twiss J, Wilburn JN, Crawford SR, Loth K, Mufti GJ. Investigation of the Impact of Myelodysplasia (MDS) From the Patients' Perspective. ASH Annual Meeting Abstracts. November 18, 2011 2011;118(21):5049-.

41. Feyer P, Kleeberg UR, Steingraber M, Gunther W, Behrens M. Frequency of side effects in outpatient cancer care and their influence on patient satisfaction--a prospective survey using the PASQOC questionnaire. Support Care Cancer. Jun 2008;16(6):567-575.

42. Arnold B, Dhar J, Parks-Vernizzi E, Debb S. Translation and linguistic validation of the FACT-Th18 for use with cancer patients with thrombocytopenia worldwide. Value in Health. 2012;15(4):A236.

43. NCT01615146. Outpatient Platelet Transfusions in Myelodysplastic Syndromes and Leukemia: the OPTIMAL Pilot. 2012. Accessed January 7th, 2013.

44. Persson L, Hallberg IR, Ohlsson O. Acute leukaemia and malignant lymphoma patients'experiences of disease, treatment and nursing care during the active treatment phase: an explorative study. European Journal of Cancer Care. 1995;4(3):133-142. 
45. On behalf of the MDS Foundation and its Board of Directors. P097 Disease burden and treatment impact associated with myelodysplastic syndromes: initial estimates. Leuk Res. 2009;33, Supplement 1(0):S115-S116.

46. Crosby RD, Kolotkin RL, Williams GR. Defining clinically meaningful change in health -related quality of life. J Clin Epidemiol. 2003;56:395-407.

47. JuniperEF, Guyatt GH, Willan A, Griffith LE. Determining a minimal important change in a disease-specific Quality of Life Questionnaire. J Clin Epidemiol. Jan 1994;47(1):81-87.

48. Slichter SJ, Kaufman RM, Assmann SF, etal. Dose of prophylactic platelet transfusions and prevention of hemorrhage. N Eng/J Med. Feb 18 2010;362(7):600-613.

49. Pendry K, Davies T. An audit of the use and wastage in the North West of England and North Wales - where have all the platelets gone? . Blood and Transfusion Matters. 2011;34:17-19.

50. Huwiler-Muntener K, Juni P, Junker C, Egger M. Quality of reporting of randomized trials as a measure of methodologic quality. J Amer Med Assoc. Jun 5 2002;287(21):2801-2804.

51. Juni P, Witschi A, Bloch R, Egger M. The hazards of scoring the quality of cl inical trials for metaanalysis. J AmerMed Assoc. Sep 15 1999;282(11):1054-1060.

52. Greenland S, O'Rourke K. On the bias produced by quality scores in meta-analysis, and a hierarchical view of proposed solutions. Biostatistics. Dec 2001;2(4):463-471.

53. The EuroQoL Group. EuroQol--a new facility for the measurement of health-related quality of life. The EuroQol Group. Health Policy. Dec 1990;16(3):199-208.

54. Brooks R. EuroQol: the current state of play. Health Policy. Jul 1996;37(1):53-72.

55. Jakobsson U, Hall berg IR, Westergren A. Exploring determinants for quality of life among older people in pain and in need of help for daily living. J Clin Nurs. Mar 2007;16(3A):95-104.

56. Lorr M, McNair DM, Heuchert JWP, Droppleman LF. POMS Profile of Mood States. 2004.

57. Bowling A. Measuring Disease. 2nd ed: Oxford University Press; 2001. 
58. Nyenhuis DL, Yamamoto C, Luchetta T, Terrien A, Parmentier A. Adult and geriatric normative data and validation of the profile of mood states. J Clin Psychol. Jan 1999;55(1):79-86.

59. Hays RD, Sherbourne CD, Mazel RM. User's manual for the medical outcomes study (MOS) core: measures of health-related quality of life: RAND Corporation; 1994.

60. Eriksson M, Lindstrom B. Validity of Antonovsky's sense of coherence scale: a systematic review. J Epidemiol Community Health. Jun 2005;59(6):460-466.

61. Bowling A. Measuring Health. 2nd ed: Oxford University Press; 1997.

62. Persson L, Hall lberg IR, Ohlsson O. Survivors of acute leukaemia and highly malignant lymphoma-retrospective views of daily life problems during treatment and when in remission. Journal of Advanced Nursing. 1997;25(1):68-78.

63. Aaronson NK, Ahmedzai S, Bergman B, et al. The European Organization for Research and Treatment of Cancer QLQ-C30: a quality-of-life instrument for use in international clinical trials in oncology. J Natl Cancer Inst. Mar 3 1993;85(5):365-376.

64. Hjermstad MJ, Fayers PM, Bjordal K, Kaasa S. Health-related quality of life in the general Norwegian population assessed by the European Organization for Research and Treatment of Cancer Core Quality-of-Life Questionnaire: the QLQ=C30 (+ 3). J Clin Oncol. Mar 1998;16(3):11881196.

65. Osoba D, Aaronson N, Zee B, Sprangers M, te Velde A. Modification of the EORTCQLQ-C30 (version 2.0) based on content validity and reliability testing in large samples of patients with cancer. The Study Group on Quality of Life of the EORTC and the Symptom Control and Quality of Life Committees of the NCl of Canada Clinical Trials Group. Qual Life Res. Mar 1997;6(2):103-108.

66. Cella DF, Tulsky DS, Gray G, et al. The Functional Assessment of CancerTherapy scale: development and validation of the general measure. J Clin Oncol. Mar 1993;11(3):570-579. 
67. Webster K, Cella D, Yost K. The Functional Assessment of Chronic Illness Therapy (FACIT) Measurement System: properties, applications, and interpretation. Health Qual Life Outcomes. 2003;1:79.

68. Cella D, Beaumont J, Webster K, Lai J-S, Elting L. Measuring the concerns of cancer patients with low platelet counts: the Functional Assessment of Cancer Therapy-Thrombocytopenia (FACT-Th) questionnaire. Support Care Cancer. 2006;14(12):1220-1231.

69. Cleeland CS, Mendoza TR, Wang XS, et al. Assessing symptom distress in cancer patients: the M.D. Anderson Symptom Inventory. Cancer. Oct 1 2000;89(7):1634-1646.

70. Cleeland CS. The M.D. Anderson Symptom Inventory User Guide [Draft]2010. Accessed 19th November 2012.

Quality of life and bleeding 


\section{Appendix I- Search Strategy}

\section{THE COCHRANE LIBRARY}

1. BLOOD PLATELETS single term (MeSH)

2. platelet* or thrombocyte*

3. 1 or 2

4. BLOOD TRANSFUSION explode all trees (MeSH)

5. transfus*:ti

6. 4 or 5

7. 3 and 6

8. PLATELET TRANSFUSION single te rm (MeSH)

9. ((platelet* or thrombocyte*) NEAR/5 (transfus* or infus* or a dminist* or requir*))

10. 7 or 8 or 9

11. THROMBOCYTOPENIA explode all trees (MeSH)

12. thrombocytopeni*

13. PLATELET COUNT single term (MeSH)

14. (platelet* Near/5 (count* or low or lower* or below or level* or reduc*))

15. 11 or 12 or 13 or 14

16. ATTITUDE TO HEALTH explode all trees (MeSH)

17. PATIENT COMPLIANCE single term (MeSH)

18. PATIENT SATISFACTION explode all trees (MeSH)

19. ADAPTATION, PSYCHOLOGICAL single term (MeSH)

20. MODELS, PSYCHOLOGICAL explode all trees (MeSH)

21. PSYCHOLOGICAL THEORY single te rm (MeSH)

22. STRESS, PYSCHOLOGICAL single term (MeSH)

23. PATIENT-CENTERED CARE single term (MeSH)

24. PSYCHOLOGY, MEDICAL single term (MeSH)

25. "common sense model*"

26. (coping NEAR/5 (s trateg* or behav*))

Quality of life and bleeding 
27. (illness NEAR/5 cogniti*)

28. ((patient* or illness* or risk*) NEAR/5 (perception* or perceiv* or perspective* or belie*))

29. (psycholog* NEAR/5 (research* or the or*))

30. 16 or 17 or 18 or 19 or 20 or 21 or 22 or 23 or 24 or 25 or 26 or 27 or 28 or 29

31. QUALITY-OF-LIFE single term (MeSH)

32. QUESTIONNAIRES explode all trees (MeSH)

33. HEALTH-STATUS explode all trees (MeSH)

34. HEALTH-STATUS-INDICATORS explode all trees (MeSH)

35. HEALTH-SURVEYS explode all trees (MeSH)

36. INTERVIEWS AS TOPIC explode all trees (MeSH)

37. HEALTH CARE SURVEYS single term (MeSH)

38. ACTIVITIES-OF-DAILY-LIVING single te rm (MeSH)

39. SELF-CARE single term (MeSH)

40. QUALITY-ADJUSTED-LIFE-YEARS single term (MeSH)

41. PSYCHOMETRICS single term (MeSH)

42. COST-OF-ILLNESS single term (MeSH)

43. LIFE-STYLE explode all trees (MeSH)

44. (QOL or HQOL or HRQOL or HRQL or PedQL* or Ped-QL*or PedsQL* or Peds-QL*)

45. (qua lity NEAR/2 life)

46. (qua lity a djusted life year* or QALY*)

47. (health NEAR/j2 (state or s tatus))

48. (well being or wellbeing)

49. 31 or 32 or 33 or 34 or 35 or 36 or 37 or 38 or 39 or 40 or 41 or 42 or 43 or 44 or 45 or 46 or 47 or 48

50. 30 or 49

51. LEUKEMI A explode all trees (MeSH)

52. LYMPHOMA explode all trees (MeSH)

53. NEOPLASMS, PLASMA CELL expl ode all tre es (MeSH)

54. MYELODYSPLASTIC-MYELOPROLIFERATIVE DISEASES explode all trees (MeSH)

55. MYELODYSPLASTICSYNDROMES explode a ll trees (MeSH)

\section{Quality of life and bleeding}


56. MYELOPROLIFERATIVE DISORDERS explode all trees (MeSH)

57. HEMATOLOGICNEOPLASMS explode all trees (MeSH)

58. (le ukemia* or leukaemia* or lymphoma* or hodgkin* or burkitt* or myeloma* or waldenstr* or plasmacytoma*)

59. (plasma cell NEAR/3 (tumor* or tumour*))

60. (myelodysplas* or myelofibrosis)

61. ((a naemia or a nemia) NEAR/2 (refractory or sideroblastic or myelophthisic))

62. ((ha ematologic* or he matologic*) NEAR/3 (malignan* or neoplasm* or ca ncer* or tumor*or tumour*))

63.51 or 5253 or 54 or 55 or 56 or 57 or 58 or 59 or 60 or 61 or 62

64. HEMORRHAGE explode all trees (MeSH)

65. (bleed* or re bleed* or hemorrhag* or haemorrhag* or bloodloss* or (blood NEXT loss*))

66. (petechia* or purpura*)

67.64 or 65 or 66

68. 15 or 63

69. 10 or 67

70. 50 and 68 and 69

\section{MEDLINE \& ERIC (Ovid)}

1. BLOOD PLATELETS/

2. (platelet* or thrombocyte*).tw.

3. 1 or 2

4. $\operatorname{exp~BLOOD~TRANSFUSION/~}$

5. transfus*.ti.

6. 4 or 5

7. 3 and 6

8. PLATELET TRANSFUSION/

9. ((platelet* or thrombocyte*) adj5 (tra nsfus* or infus* or a dminist* or requir*)).tw.

10. or/7-9

11. exp THROMBOCYTOPENIA

12. thrombocytopeni*.tw

\section{Quality of life and bleeding}


13. PLATELET COUNT/

14. (platelet* a dj5 (count* or low or lower* or below or level* or reduc*)).tw.

15. or/11-14

16. exp ATTITUDE TO HEALTH/

17. PATIENT COMPLIANCE/

18. exp PATIENT SATISFACTION/

19. ADAPTATION, PSYCHOLOGICAL/

20. $\operatorname{exp~MODELS,~PSYCHOLOGICAL/~}$

21. PSYCHOLOGICAL THEORY/

22. STRESS, PYSCHOLOGICAL/

23. PATIENT-CENTERED CARE/

24. PSYCHOLOGY, MEDICAL/

25. common sensemodel*.tw.

26. (coping adj5 (strateg* or behav*)).tw.

27. (illness adj5 cogniti*).tw.

28. ((patient* or illness* or risk*) adj5 (perception* or perceiv* or perspective* or belie*)).tw.

29. (psycholog* a dj5 (research* or theor*)).tw.

30. or/16-29

31. QUALITY-OF-LIFE/

32. PSYCHOLOGY.fs.

33. exp QUESTIONNAIRES/

34. exp HEALTH-STATUS/

35. exp HEALTH-STATUS-INDICATORS/

36. exp HEALTH-SURVEYS/

37. exp INTERVIEWS AS TOPIC/

38. HEALTH CARE SURVEYS/

39. ACTIVITIES-OF-DAILY-LIVING/

40. SELF-CARE/

41. QUALITY-ADJUSTED-LIFE-YEARS/

Quality of life and bleeding 
42. PSYCHOMETRICS/

43. COST-OF-ILLNESS/

44. exp LIFE-STYLE/

45. (QOL or HQOL or HRQOL or HRQL or PedQL* or Ped-QL*or PedsQL* or Peds-QL*).tw.

46. (quality a dj2 life).tw.

47. (qua lity a djusted life ye ar* or QALY*).tw.

48. (health adj2 (state or s tatus)).tw.

49. (well being or wellbeing).tw.

50. or/31-49

51. 30 or 50

52. exp LEUKEMIA/

53. exp LYMPHOMA/

54. $\exp$ NEOPLASMS, PLASMA CELL/

55. exp MYELODYSPLASTIC-MYELOPROLIFERATIVE DISEASES/

56. $\operatorname{exp~MYELODYSPLASTICSYNDROMES/~}$

57. exp MYELOPROLIFERATIVE DISORDERS/

58. exp HEMATOLOGICNEOPLASMS/

59. (le ukemia* or leukaemia* or lymphoma* or hodgkin* or burkitt* or myeloma* or waldenstr* or plasmacytoma*).tw.

60. (plasma cell adj3 (tumor* or tumour*)).tw.

61. (myelodysplas* or myelofibrosis).tw.

62. ((a naemia or a nemia) adj2 (refractory or sideroblastic or myelophthisic)).tw.

63. ((ha ematologic* or he matologic*) adj3 (malignan* or neoplasm* or ca ncer* or tumor*or tumour*)).tw.

64. or/52-63

65. exp Hemorrhage/

66. (bleed* or rebleed* or hemorrhag* or haemorrhag* or bloodloss* or (blood a dj loss*)).tw.

67. (petechia* or purpura*).tw.

68. or/65-67

69. 15 or 64

70. 10 or 68

Quality of life and bleeding 
71. 69 and 70

72. 71 and 51

73. $\exp *$ LEUKEMIA/

74. exp *LYMPHOMA/

75. exp *NEOPLASMS, PLASMA CELL/

76. exp *MYELODYSPLASTIC-MYELOPROLIFERATIVE DISEASES/

77. exp *MYELODYSPLASTICSYNDROMES/

78. exp *MYELOPROLIFERATIVE DISORDERS/

79. $\exp *$ HEMATOLOGICNEOPLASMS/

80. (le ukemia* or leukaemia* or lymphoma* or hodgkin* or burkitt* or mye loma* or waldenstr* or plasmacytoma*).ti.

81. (plasma cell adj3 (tumor* or tumour*)).ti.

82. (myelodysplas* or myelofibrosis).ti.

83. ((a naemia or a nemia) adj2 (refractory or sideroblastic or myelophthisic)).ti.

84. ((ha ematologic* or he matologic*) adj3 (malignan* or neoplasm* or ca ncer* or tumor*or tumour*)).ti

85. or/73-84

86. 30 and 50 and 85

87.72 or 86

\section{EMBASE (Ovid)}

\section{THROMBOCYTE/}

2. (platelet* or thrombocyte*).tw.

3. 1 or 2

4. $\operatorname{exp~BLOOD~TRANSFUSION/~}$

5. transfus*.ti

6. 4 or 5

7. 3 and 6

8. THROMBOCYTE TRANSFUSION/

9. ((platelet* or thrombocyte*) adj5 (tra nsfus* or infus* or a dminist* or requir*)).tw.

10. or/7-9

\section{Quality of life and bleeding}


11. $\exp$ THROMBOCYTOPENIAV

12. thrombocytopeni*.tw.

13. THROMBOCYTE COUNT/

14. (platelet* a dj5 (count* or low or lower* or below or level* or reduc*)).tw.

15. or/11-14

16. exp MYELOPROLIFERATIVE DISORDER/

17. exp LYMPHOMA/

18. exp MALIGNANT PLASMACYTOMA/

19. exp MYELODYSPLASTICSYNDROME/

20. exp HEMATOLOGICMALIGNANCY/

21. (le ukemia* or leukaemia* or lymphoma* or hodgkin* or burkitt* or mye loma* or waldenstr* or plasmacytoma*).tw.

22. (plasma cell adj3 (tumor* or tumour*)).tw.

23. (myelodysplas* or myelofibrosis).tw.

24. ((a naemia or a nemia) adj2 (refractory or sideroblastic or mye lophthisic)).tw.

25. ((ha ematologic* or he matologic*) adj3 (malignan* or neoplasm* or ca ncer* or tumor*or tumour*)).tw.

26. or $/ 16-25$

27. 15 or 26

28. $\operatorname{exp~BLEEDING/~}$

29. (ble ed* or rebleed* or hemorrhag* or haemorrhag* or bloodloss* or (blood a dj loss*)).tw.

30. (petechia* or purpura*).tw.

31. or/28-30

32. 10 or 31

33. 27 and 32

34. exp *MYELOPROLIFERATIVE DISORDER/

35. exp *LYMPHOMA/

36. exp *MALIGNANT PLASMACYTOMA/

37. exp *MYELODYSPLASTIC SYNDROME/

38. exp *HEMATOLOGICMALIGNANCY/

39. (le ukemia* or leukaemia* or lymphoma* or hodgkin* or burkitt* or mye loma* or waldenstr* or plasmacytoma*).ti.

\section{Quality of life and bleeding}


40. (plasma cell adj3 (tumor* or tumour*)).ti.

41. (myelodysplas* or myelofibrosis).ti.

42. ((a naemia or a nemia) adj2 (refractory or sideroblastic or myelophthisic)).ti.

43. ((ha ematologic* or he matologic*) adj3 (malignan* or neoplasm* or ca ncer* or tumor*or tumour*)).ti.

44. or/34-43

45. exp QUALITY-OF-LIFE/

46. HEALTH SURVEY/

47. QUESTIONNAIRE/

48. $\operatorname{exp~HEALTH-STATUS/~}$

49. $\exp$ NAMED-INVENTORIES-QUESTIONNAIRES-AND-RATING-SCALES/

50. OUTCOMES RESEARCH/

51. SCORING SYSTEM/

52. RATING-SCALE/

53. FUNCTIONAL-ASSESSMENT/

54. SELF-REPORT/

55. (QOL or HQOL or HRQOL or HRQL or PedQL* or Ped-QL*or PedsQL* or Peds-QL*).tw.

56. (qua lity a dj2 life).tw.

57. (qua lity a djusted life year* or QALY*).tw.

58. (health adj2 (state or status)).tw.

59. (well being or wellbeing).tw.

60. or/45-59

61. ATTITUDE TO HEALTH/

62. exp PATIENT ATTITUDE/

63. ADAPTIVE BEHAVIOR/

64. PSYCHOLOGICAL MODEL/

65. PSYCHOLOGICAL THEORY/

66. MENTALSTRESS/

67. MEDICAL PSYCHOLOGY/

68. common sensemodel*.tw.

\section{Quality of life and bleeding}


69. (coping adj5 (strateg* or behav*)).tw.

70. (illness adj5 cogniti*).tw.

71. ((patient* or illness* or risk*) adj5 (perception* or perceiv* or perspective* or belie*)).tw.

72. (psycholog* a dj5 (research* or theor*)).tw.

73. or/61-72

74. 60 or 73

75. 33 and 74

76. 44 and 60 and 73

77. 75 or 76

\section{CINAHL \& PSYCINFO (NLH)}

1. BLOOD PLATELETS/

2. (platelet* or thrombocyte*).tw.

3. 1 or 2

4. $\operatorname{exp~BLOOD~TRANSFUSION/~}$

5. transfus*.ti.

6. 4 or 5

7. 3 and 6

8. PLATELET TRANSFUSION/

9. ((platelet* adj5 transfus*) or (platelet a dj5 infus*) or (platelet* a dj5 a dminist*) or (platelet* adj5 requir*)).tw.

10. ((thrombocyte* a dj5 tra nsfus*) or (thrombocvte* a dj5 infus*) or (thromocyte* adj5 administ*) or (thrombocyte* adj5 requir*)).tw.

11. 7 or 8 or 9 or 10

12. $\exp$ THROMBOCYTOPENIA/

13. thrombocytopeni*.tw.

14. PLATELET COUNT/

15. ((platelet* adj5 count*) OR (platelet* adj5 low) OR (platelet* adj5 lower*) OR (platelet* adj5 below) OR (platelet* adj5 level*) OR (platelet* adj5 reduc*)).ti,ab

16. 12 OR 13 OR 14 OR 15

Quality of life and bleeding 
17. exp ATTITUDE TO HEALTH/

18. HEALTH BELIEFS/

19. ATTITUDE TO ILLNESS/

20. exp PATIENT COMPLIANCE/

21. ADAPTATION, PSYCHOLOGICAL/

22. $\operatorname{exp~MODELS,~PSYCHOLOGICAL/~}$

23. PSYCHOLOGICAL THEORY/

24. STRESS, PSYCHOLOGICAL/

25. $\exp$ PATIENT CENTRED CARE/

26. "common sense model*".ti,ab

27. ((coping adj5 strateg*) or (coping adj5 behav*)).ti,ab

28. (illness adj5 cogniti*).ti,ab

29. ((patient* a dj5 perception*) or (patient* a dj5 perceiv*) or (patient* adj5 perspective*) or (patient* a dj5 belie*)).ti,ab

30. ((illness* a dj5 perception*) or (illness* adj5 perceiv*) or (illness* a dj5 perspective*) or (illness*a dj5 belie*)).ti,ab

31. ((risk* a dj5 perception*) or (risk* a dj5 perceiv*) or (risk* adj5 perspective*) or (risk* a dj5 belie*)).ti,ab

32. ((psycholog* a dj5 research*) or (psycho* adj5 theor*)).ti,ab

33. 16 or 17 or 18 or 19 or 20 or 21 or 22 or 23 or 24 or 25 or 26 or 27 or 28 or 29 or 30 or 31 or 32

34. QUALITY OF LIFE/

35. exp INSTRUMENT BY NAME/

36. exp QUESTIONNAIRES/

37. exp HEALTH STATUS/

38. HEALTH STATUS INDICATORS/

39. exp SURVEYS/

40. exp SABA CLINICAL CARE NURSING INTERVENTIONS/

41. QUALITY ADJUSTED LIFE YEARS/

42. PSYCHOMETRICS/

43. exp LIFE STYLE/

44. (QOL or HQOL or HRQOL or HRQL or PedQL* or Ped-QL*or PedsQL* or Peds-QL*).ti,ab

45. (qua lity a dj2 life).ti, ab

\section{Quality of life and bleeding}


46. (qua lity a djusted life year* or QALY*).ti,ab

47. ((health a dj2 state) or (health adj2 status)).ti,ab

48. (well being or wellbeing).ti,ab

49. 34 or 35 or 36 or 37 or 38 or 39 or 40 or 41 or 42 or 43 or 44 or 45 or 46 or 47 or 48

50. 33 or 49

51. exp LEUKEMIA/

52. exp LYMPHOMA/

53. $\operatorname{exp~MYELODYSPLASTICSYNDROMES/~}$

54. exp MYELOPROLIFERATIVE DISORDERS/

55. exp HEMATOLOGICNEOPLASMS/

56. (le ukemia* or leukaemia* or lymphoma* or hodgkin* or burkitt* or mye loma* or waldenstr* or plasmacytoma*).ti,ab

57. ("plasma cell" adj3 tumor*) or ("plasma cell" adj3 tumour*)).ti,ab

58. (myelodysplas* or myelofibrosis).ti,ab

59. ((a naemia a dj2 re fractory) or (anaemia a dj2 sideroblastic) or (anaemia adj2 mye lophthisic)).ti,ab

60. ((a nemia a dj2 refractory) or (a nemia adj2 sideroblastic) or (anemia a dj2 myelophthisic)).ti,ab

61. ((ha ematologic* a dj3 malignan*) or (haematologic* a dj3 neoplasm*) or (haematologic* adj3 cancer*) or (haematologic* a dj3 tumor*) or (haematologic* adj3 tumour*)).ti,ab

62. ((hematologic* adj3 malignan*) or (hematologic* adj3 neoplasm*) or (hematologic* adj3 ca ncer*) or (hematologic* a dj3 tumor*) or (he matologic* a dj3 tumour*)).ti,ab

63. 51 or 5253 or 54 or 55 or 56 or 57 or 58 or 59 or 60 or 61 or 62

64. $\operatorname{exp~HEMORRHAGE/~}$

65. (bleed* or re bleed* or hemorrhag* or haemorrhag* or bloodloss* or (blood a dj loss*)).ti,ab

66. (petechia* or purpura*).ti,ab

67.64 or 65 or 66

68. 11 or 67

69. 16 or 63

70. 68 and 69 and 50

\section{ISI PROCEEDINGS}

\section{Quality of life and bleeding}


"quality of life" OR QOL OR HQOL OR HRQOL OR HRQL OR PedQL* OR Ped-QL*OR PedsQL* OR Peds-QL* OR questionnaire* OR survey*

AND

leukemia* OR leukaemia* OR lymphoma* OR hodgkin* OR burkitt* OR myeloma* OR waldenstr* OR plasmacytoma* AND

bleed* OR re bleed* OR hemorrhag* OR haemorrhag* OR bloodloss* OR petechia* OR purpura OR "platelet tra nsfusion*"

\section{CLINICALTRIALS.GOV}

Search Terms: "Quality of Life" OR QALY OR QOL OR HQOL OR HRQOL OR HRQL OR PedQL OR Ped-QL OR PedsQL or Peds-QL OR questionnaire OR questionnaires OR survey OR surveys

Conditions: leukemia OR leukaemia OR Iymphoma OR hodgkin OR mye loma OR plasmacytoma OR mye lodysplasia OR myel odys plastic OR myeloproliferative OR thrombocytopenia

\section{ISRCTN}

("Qua lity of Life" OR QALY OR QOL OR HQOL OR HRQOL OR HRQL OR PedQL OR Ped-QL OR PedsQL or Peds-QL or questionnaire OR questionnaires OR survey OR surveys) AND (leukemia OR leukaemia OR lymphoma OR hodgkin OR myeloma OR plasmacytoma OR myelodysplasia OR myelodysplastic OR myeloproliferative OR thrombocytopenia OR thrombocytopenic) AND (ha e morrhage OR hemorrhage OR haemorrhaging OR he morrhaging OR bleeding OR platelet OR platelets OR petechiae OR purpura)

\section{WHO ICTRP}

Condition: leukemia OR leukaemia OR Iymphoma OR hodgkin OR myeloma OR plasmacytoma OR myelodysplasia OR myelodys plastic OR myeloproliferative OR thrombocytopenia OR thrombocytopenic Intervention: "Quality of Life" OR QALY OR QOL OR HQOL OR HRQOL OR HRQL OR PedQL OR Ped-QL OR PedsQL or Peds-QL or questionnaire OR questionnaires OR survey OR surveys

PUBMED (e-publications) \& TRANSFUSION EVIDENCE LIBRARY (www.transfusionevidencelibrary.com)

\#1 "Qua lity of Life" OR QALY OR QOL OR HQOL OR HRQOL OR HRQL OR PedQL OR Ped-QL OR PedsQL or Peds-QL or question naire OR questionnaires OR s urvey OR surveys

Quality of life and bleeding 
\#2 le ukemi* OR leukaemia* OR lymphoma OR Hodgkin* OR myeloma OR plasmacytoma OR myelodysplas* OR myeloproliferative OR thrombocytopeni*

\#3 ha e morrhag* OR hemorrhag* OR bleed* OR platelet OR platelets OR petechia* OR purpura

\#4 \#1 AND \#2 AND \#3

\#5 publisher[sb]NOT pubstatusnihms

\#6 \#4 AND \#5

Quality of life and bleeding 


\section{Appendix 2:}

\section{Data recorded on data extraction form}

1. General information (e.g. study ID, citation of paper, objectives of the trial).

2. Study details (e.g. trial design, location, treatment allocation, randomisation, blinding, inclusion and exclusion criteria, reasons for exclusion, comparability of groups if appli cable, length of follow up) 3. Characteristics of participants at baseline (e.g. age, gender, total number recruited, total number randomised (if appropriate), total number analysed, types of haematological disease, lost to follow -up numbers, drop outs (percentage in each arm))

4. Quality of Life Tool (Conceptual (A priori hypothesis, rationale for instrument used), Measurement (psychometric properties, cultural validity, adequacy of domains), Methodology (instrument administration, baseline compliance, timing of assessments, missing data) Interpretation (clinical significance)).

5. Interventions (if performed)

6. Outcomes measured (e.g. quality of life in bleeding and non-bleeding patients, number and severity of bleeding episodes, mortality).

\section{Risk of bias assessment Non-randomised studies}

- Appropriate source population (selection bias)

- Appropriate measurement methods for both exposure(s) and or outcome(s) (detection bias)

- Appropriate methods to deal with any design-specific issues such as recall bias, interviewer bias, biased loss to follow-up or blinding (performance bias \& attrition bias)

- Appropriate design and/or analytical methods (confounding)

- Appropriate use of statistics for primary analysis of effect (reporting bias) 
- Declaration of conflict of interest or identification of funding sources (other bias).

Quality of life and bleeding 


\section{Appendix 3: Screening of full text for systematic review QoL/IIIness perceptions}

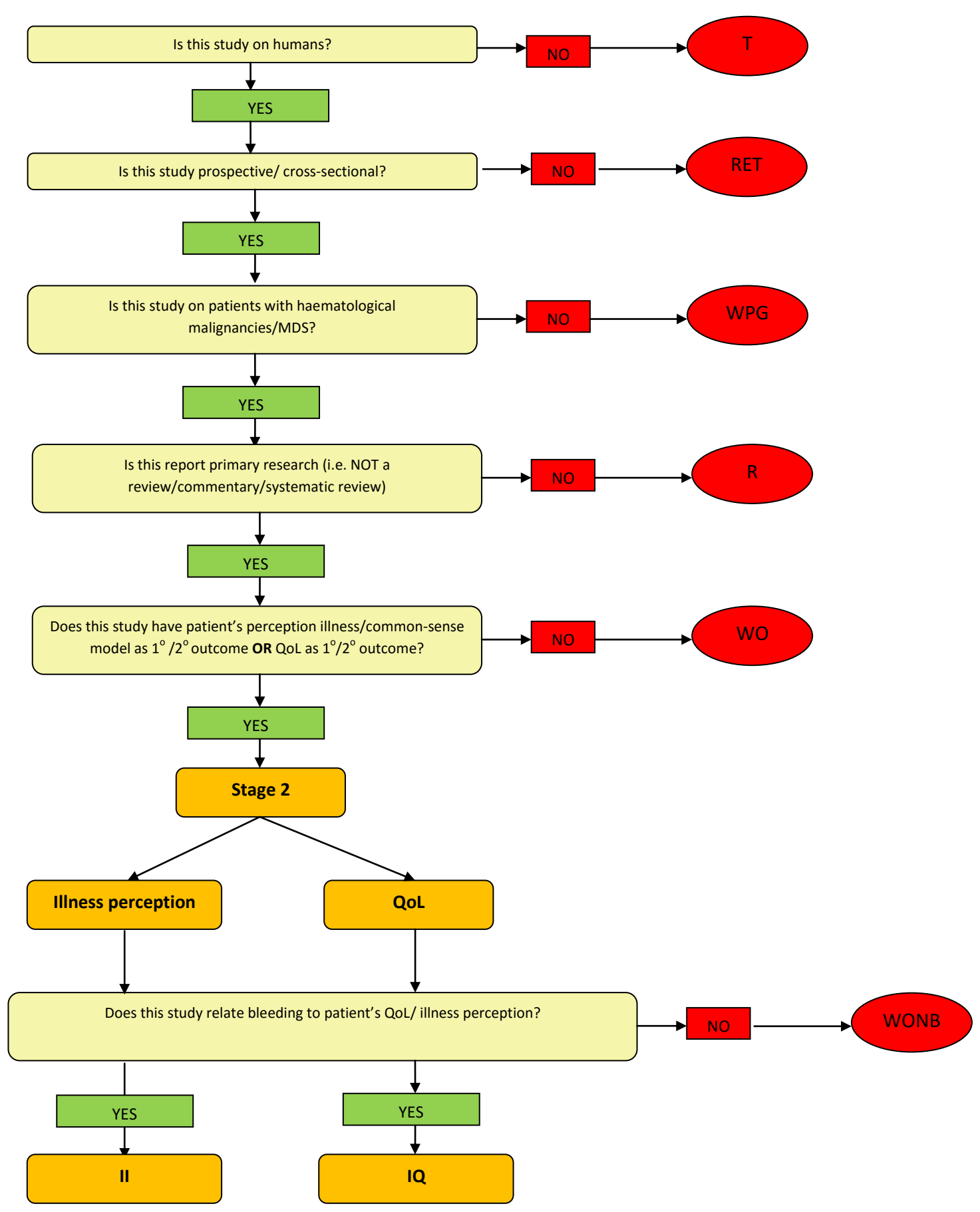

II = Include illness perception; IQ = Include QoL; R = Review; $T=$ Theoretical; WO = Wrong outcome; WONB $=$ Wrong outcome not bleeding WPG = wrong patient group

Quality of life and bleeding 


\section{Appendix 4 - Excluded Studies}

- Retrospective $(n=15)[1-15]$

- Wrong patient group $(n=5)[16-20]$

- $\operatorname{Review}(\mathrm{n}=29)[21-49]$

- No patient related outcome reported $(n=42)[50-91]$

- No bleeding reported $(\mathrm{n}=204)[92-295]$

1. Adam C, Bas K, Mailliard MC, Pierot C. [Suffering from caring]. Revue de L'Infirmiere 1991; 41: 4448.

2. Adekale M. American Society of Hematology--44th Annual Meeting and Exposition. Drug highlights I. 6-10 December 2002, Philadelphia, PA, USA. IDrugs: the investigational drugs journal 2003; 6: 1-3.

3. Becze E. Clinical, communication, and coping knowledge: the keys to helping MDS patients on their journey to hope. ONS Connect 2007; 22: 59-60.

4. D'Orazio Al, Fisher MD. 43rd Annual Meeting of the American Society of Hematology, December 711, 2001, Orlando, Florida. Clin Lymphoma 2002; 2: 205-208.

5. Dobb J, Small M. Crying together, laughing together. Nurs Times 1997; 93: 36-37.

6. Dorsen PJ. When one of 'us' has cancer. Minn Med 1993; 76: 8-9.

7. Feng AY, Hallmeyer S, Peace D et al. Integrative tumor board: Recurrent lymphoma. Integr Cancer Ther 2004; 3: 238-256.

8. Fochtman D. How adolescents live with leukemia. Cancer Nurs 1979; 2: 27-31.

9. Greenfield RM. Reflections on leukemia and adult stem-cell transplantation: some personal psychological factors. Palliative \& Supportive Care 2007; 5: 415-418.

10. Hoerni B, Zittoun R, Rojouan J et al. [Psychosocial repercussions of the the treatment of Hodgkin's disease. Assessment by questionnaire with 150 patients]. Bulletin du Cancer 1986; 73: 620-626.

11. Jones LW, Courneya KS, Vallance JKH et al. Association between exercise and quality of life in multiple myeloma cancer survivors. Supportive Care in Cancer 2004; 12: 780-788.

12. Karpouzis A, Tsatalas C, Sivridis E et al. Acquired reactive perforating collagenosis associated with myelodysplastic syndrome evolving to acute myelogenous leukaemia. Australasian Journal of Dermatology 2004; 45: 78-79. 
13. Langeveld NE, van Veldhuizen AM, Last BF, Ripken SP. [Quality of life in young adults who had cancer at an early age]. Oncologica 1997; 14: 44-46.

14. Persson L, Hallberg IR, Ohlsson O. Survivors of acute leukaemia and highly malignant lymphomaretrospective views of daily life problems during treatment and when in remission. Journal of Advanced Nursing 1997; 25: 68-78.

15. Stalfelt AM, Zettervall $O$. Quality of life in young patients with chronic myelocytic leukaemia during intensive treatment including interferon. Leukemia Research 1997; 21: 775-783.

16. Arnold B, Dhar J, Parks-Vernizzi E, Debb S. Translation and linguistic validation of the FACT-Th18for use with cancer patients with thrombocytopenia world wide. Value in Health 2012; 15: A236.

17. Boelaars MFP, Peters M, Fijnvandraat K. Evaluation of a self-admin istrated pediatric bleeding questionnaire measuring bleeding severity in children. Thrombosis and Haemostasis 2012; 108: 1006-1007.

18. Clarke S-A, Davies H, Jenney Met al. Parental communication and children's behaviour following diagnosis of childhood leukaemia. Psycho-Oncology 2005; 14: 274-281.

19. Feyer P, Kleeberg UR, Steingraber M et al. Frequency of side effects in outpatient cancer care and their influence on patient satisfaction--a prospective survey using the PASQOC que stionnaire. Supportive Care in Cancer 2008; 16: 567-575.

20. Suzuki Y, Tokuda Y, Fujiwara Y et al. Weekly Epoetin Beta Maintains Haemoglobin Levels and Improves Quality of Life in Patients with Non-Myeloid Malignancies Receiving Chemotherapy. Japanese Journal of Clinical Oncology 2008; 38: 214-221.

21. Ageno W. Anothergood reason for not ignoring thromboprophylaxis in acutely ill medical patients. Journal of Thrombosis and Haemostasis 2004; 2: 1889-1891.

22. Atallah E, Kantarjian H, Garcia-Manero G. The Role of Decitabine in the Treatment of Myelodysplastic Syndromes. Expert Opinion on Pharmacotherapy 2007; 8: 65-71.

23. Atwood KC. Patients have a "CAM" knowledge gap-But who will fill it? American Journal of Hematology 2009; 84: 788-789.

24. Baylin SB, Mufti GJ. Myelodysplastic syndromes (MDSs) and acute myelogenous leukemia (AML) comprise a closely linked continuum of malignant hematologic diseases. Introduction. Nat Clin Pract Oncol 2005; 2 Suppl 1: S1-3.

25. Broers S. Invited commentary to the paper "Coping and survival in patients with leukemia undergoing allogeneic bone marrow transplantation-long term follow-up of a prospective study" by Norbert Grulke et al. (OJPR/2004/3520). Journal of Psychosomatic Research 2005; 59: 347-348. 
26. Campbell C, Bramwell V, Charette M, Oliver T. Role of colony-stimulating factor in patients receiving myelosuppressive chemotherapy for treatment of cancer. Current Oncology 2003; 10: 102-126.

27. Chauncey TR. Autologous bone marrow transplantation improves disease free survival but not overall survival in people with acute myeloid leukaemia: Abstracted from: Nathan PC, Sung L, Crump $\mathrm{M}$, Beyene J. Consolidation therapy with autologous bone marrow transplantation in adults with acute myeloid leukemia: a meta-analysis. Journal of the National Cancer Institute 2004;96:38-45. Cancer Treatment Reviews 2004; 30: 483-487.

28. Detwiler DA. The positive function of denial. Journal of Pediatrics 1981; 99: 401-402.

29. Efficace F, Kemmler G, Vignetti Met al. Health-related quality of life assessment and reported outcomes in leukaemia randomised controlled trials -A systematic review to eval uate the added value in supporting clinical decision making. European Journal of Cancer 2008; 44: 1497-1506.

30. Efficace F, Novik A, Vignetti Met al. Health-related quality of life and symptom assessment in clinical research of patients with hematologic malignancies: where are we now and where do we go from here? Haematologica 2007; 92: 1596-1598.

31. Efficace F, Vignetti M, Mandelli F. Asking patients with hematological malignancies: 'how do you feel?' Does it really provide independent prognostic information for survival? European Journal of Haematology 2009; 82: 484-485.

32. Feeny D, Furlong WJ, Barr RD. Re: Hinds et al. The Health Utilities Ind ex 3 invalidated. Cancer Nurs. 2007;30(3):169-177. Cancer Nurs 2008; 31: 261-262.

33. Ganly P, Spearing R. Treatment with intravenous immunoglobulin is not a panacea but should be limited to those who can benefit. New Zealand Medical Journal 2006; 119: 1246.

34. Gobel A, Lubrich B. [Supportive therapy for myelodysplastic syndrome (MDS). Indispensable pillar in the multimodal treatment concept]. Pharm Unserer Zeit 2010; 39: 228-233.

35. Haddad A. Adolescent has "had enough" with cancer therapy. RN 2002; 65: 25-26.

36. Hartigan B. Support strategies and issues in leukaemia and related blood diseases. Cancer Forum 1995; 19: 292-294.

37. Henry DH. Recombinant human erythropoietin for the treatment of anemia in patients with advanced cancer. Seminars in Hematology 1993; 30: 12-16.

38. Honemann D, Prince HM. Myeloma, thalidomide and thrombosis. Leukemia \& Lymphoma 2006; 47: 2273-2275.

39. Hoots WK. Hemorrhage following hematopoetic stem cell transplantation--which arrows belong in the quiver? J Thromb Haemost 2005; 3: 1933-1934. 
40. Invernizzi R, Cazzola M. Continuing Medical Education. Haematologica 2004; 89: 1149-1152.

41. Kelaidi C, Eclache V, Fenaux P. The role of lenalidomide in the management of myelodysplasia with del 5q. British Journal of Haematology 2008; 140: 267-278.

42. Koenigsmann M, Koehler M, Franke A, Frommer J. Acute leukaemia in adults: researching the patient's perspective. Leukemia 2005; 20: 206-207.

43. Loaiza-Bonilla A, Gore S, Carraway H. Novel approaches for myelodysplastic syndromes: Beyond Hypomethylating agents. Current Opinion in Hematology 2010; 17.

44. Pickard AS, Topfer L-A, Feeny DH. A Structured Review of Studies on Health-Related Quality of Life and Economic Evaluation in Pediatric Acute Lymphoblastic Leukemia. JNCI Monographs 2004; 2004: $102-125$

45. Pui CH, Pei D, Campana D et al. Intensive chemotherapy can dramatcally boost survival of older teenage leukemia patients. International Journal of Cancer Research 2011; 7: 186-187.

46. Siddiqui M, Asif A, Scott L. Azacitidine: In Myelodysplastic Syndromes. Drugs 2005; 65: 1781-1789.

47. Stauder R. The challenge of individualised risk assessment and therapy planning in elderly high-risk myelodysplastic syndromes (MDS) patients. Annals of Hematology 2012; 91: 1333-1343.

48. Yellen SB, Cella DF, Bonomi A. Quality of life in people with Hodgkin's disease. Oncology (Williston Park) 1993; 7: 41-45; discussion 46, 50-42.

49. Updates from the 2007 Multinational Association of Supportive Care in Cancer International Symposium. Journal of Supportive Oncology 2008; 6: 140-142.

50. Adamoli L, Deasy-Spinetta P, Corbetta A et al. School functioning for the child with leukemia in continuous first remission: screening high-risk children. Pediatr Hematol Oncol 1997; 14: 121-131.

51. Ades L, Boehrer S, Prebet T et al. Efficacy and safety of lenal idomide in intermediate-2 or high-risk myelodysplastic syndromes with 5q deletion: results of a phase 2 study. Blood 2009; 113: 39473952.

52. Akaho R, Sasaki T, Yoshino M et al. Bone marrow transplantation in subjects with mental disorders. Psychiatry and Clinical Neurosciences 2003; 57: 311-315.

53. Amadori S, Suciu S, Stasi R et al. Gemtuzumab ozogamicin (Mylotarg) as single-agent treatment for frail patients 61 years of age and older with acute myeloid leukemia: final results of AML-15B, a phase 2 study of the European Organisation for Research and Treatment of Cancer and Gruppo Italiano Malattie Ematologiche dell'Adulto Leukemia Groups. Leukemia 2005; 19: 1768-1773.

54. Arora NK, Weaver KE, Clayman ML et al. Physicians' decision-making style and psychosocial outcomes among cancer survivors. Patient Education and Counseling 2009; 77: 404-412. 
55. Avvisati G, ten Cate JW, Buller HR, Mandelli F. Tranexamic acid for control of haemorrhage in acute promyelocytic leukaemia. Lancet 1989; 2: 122-124.

56. Bartzoudis D, Karpouza A, Piperidou A, Papadopoulou M. 337 Erythropoietin in patients with myelodysplastic syndrome of refractory anemia and refractory anemia with excess blasts-1 subtypes; efficacy and prognostic factors. Leukemia Research 2011; 35, Supplement 1: S135.

57. Benito RJ, Carbonell TF, del Pino PJ et al. [Benefits of splenectomy in the treatment of chronic leukemia]. [Spanish]. Revista Clinica Espanola 1990; 186: 108-111.

58. Bernstein SH, Nademanee AP, Vose JMet al. A Multicenter Study of Platelet Recovery and Utilization in Patients After Myeloablative Therapy and Hematopoietic Stem CellTransplantation. Blood 1998; 91: 3509-3517.

59. Bezwoda WR, Seymour L, Ariad S, MacPhail P. Acute lymphoblastic leukaemia in adults Prognostic factors and 10 year treatment results. Leukemia and Lymphoma 1991; 5: 347-355.

60. Blaise D, Kuentz M, Fortanier C et al. Randomized Trial of Bone Marrow Versus Lenograstim-Primed Blood Cell Allogeneic Transplantation in Patients With Early-Stage Leukemia: A Report From the Société Française de Greffe de Moelle. Journal of Clinical Oncology 2000; 18: 537.

61. Blay JY, Le Cesne A, Mermet C et al. A Risk Model for Thrombocytopenia Requiring Platelet Transfusion After Cytotoxic Chemotherapy. Blood 1998; 92: 405-410.

62. Blumberg N, Heal JM. Mortality risks, costs, and decision making in transfusion medicine. American Journal of Clinical Pathology 2000; 114: 934-937.

63. Bolanos-Meade J, Guo C, Gojo I, Karp JE. A phase II study of timed sequential therapy of acute myelogenous leukemia (AML) for patients over the age of 60: Two cycle timed sequential therapy with topotecan, ara-C and mitoxantrone in adults with poor-risk AML. Leukemia Research 2004; 28 : 571-577.

64. Burnett AK, Milligan D, Prentice AG et al. A comparison of low-dose cytarabine and hydroxyurea with or without all-trans retinoic acid for acute myeloid leukemia and high-risk myelodys plastic syndrome in patients not considered fit for intensive treatment. Cancer 2007; 109: 1114-1124.

65. Camera A, Annino L, Chiurazzi F et al. GIMEMA ALL - Rescue 97: a salvage strategy for primary refractory or relapsed adult acute lymphoblastic leukemia. Haematologica 2004; 89: 145-153.

66. Castrini G, Pappalardo G. Splenectomy in early chronic myeloid leukemia. Int Surg 1979; 64: 21-26.

67. Chan G, DiVenuti G, Miller K. Danazol for the treatment of thrombocytopenia in patients with myelodysplastic syndrome. American Journal of Hematology 2002; 71: 166-171. 
68. Chang H, Kuo M-C, Shih L-Y et al. Clinical bleeding events and laboratory coagulation profiles in acute promyelocyticleukemia. European Journal of Haematology 2012; 88: 321-328.

69. Chern JJ, Tsung AJ, Humphries W et al. Clinical outcome of leukemia patients with intracranial hemorrhage. Journal of Neurosurgery 2011; 115: 268-272.

70. Couban S, Dranitsaris G, Andreou P et al. Clinical and economic analysis of allogeneic peripheral blood progenitor cell transplants: a Canadian perspective. Bone Marrow Transplantation 1998; 22: 1199-1205.

71. Drazen JM, Desai NR, Green P. Fighting On. New England Journal of Medicine 2009; 360: 444-445.

72. Efficace $F$, Alimena $G$, Voso MT et al. Involvement in treatment decisions, desire for prognostic information and quality of life in high-risk myelodysplastic syndromes: The physician's perspective. Leukemia Research 2011; 35: S57-S58.

73. Ferreri AJ, CordioS, Ponzoni M, Villa E. Non-surgical treatment with primary chemotherapy, with or without radiation therapy, of stage I-II high-grade gastric lymphoma. Leukemia \& Lymphoma 1999; 33: 531-541.

74. Gandhi V, Burger JA. Bendamustine in B-Cell Malignancies: The New 46-Year-Old Kid on the Block. Clinical Cancer Research 2009; 15: 7456-7461.

75. GanslerT, Kepner J, Willacy E et al. Evolving information prio rities of hematologic cancer survivors, caregivers, and other relatives. J Cancer Educ 2010; 25: 302-311.

76. Grulke N, Bailer H, Hertenstein B et al. Coping and survival in patients with leukemia undergoing allogeneic bone marrow transplantation--long-term follow-up of a prospective study. J Psychosom Res 2005; 59: 337-346.

77. Indrak K, Hubacek J, Mayer J et al. [Comparison of the effectiveness of idarubicin (Zavedos) and mitoxantrone (Refador) in induction the rapy of acute myeloid leukemia in elderly patients (55-75) (a prospective multicenter randomized study conducted 1998-2000]. Vnitr Lek 2001; 47 Suppl 1: 4856.

78. Juliusson G, Christiansen I, Hansen MM et al. Oral cladribine as primary therapy for patients with Bcell chronic lymphocyticleukemia. Journal of Clinical Oncology 1996; 14: 2160-2166.

79. Leitch H, Chase J, Vickars L. Red blood cell transfusion independence following the initiation of iron chelation therapy in myelodysplastic syndrome. A case report and review of the literature. Haematologica 2009; 94: 539. 
80. Loberiza FR, Jr., Sullivan A, Matsuyama R et al. Psychological Correlates of Having Ad vance Care Planning in Patients with Hematological Malignancies. ASH Annual Meeting Abstracts 2009; 114: $72-$

81. Lyons RM. Clinical roundtable monograph. Choosing an appropriate therapy for lower-risk MDS in the community setting. Clin Adv Hematol Oncol 2009; 7: S5-7.

82. Mhlbacher A, Berndt K, Schreder C, Nbling M. Preferences in multiple myeloma treatment - what do physicians think? Value in Health 2009; 12: A51.

83. Russell J, Larratt L, Brown C et al. Allogeneic blood stem cell and bone marrow transplantation for acute myelogenous leukemia and myelodysplasia: influence of stem cell source on outcome. Bone Marrow Transplant 1999; 24: 1177-1183.

84. Seymour JF, Fenaux P, Silverman LR et al. Effects of azacitidine compared with conventional care regimens in elderly ( $\geq 75$ years) patients with higher-risk myelodysplastic syndromes. Critical Reviews in Oncology/Hematology 2010; 76: 218-227.

85. Sharan $P$, Mehta $M$, Choudhry VP. Coping and adaptation in parents of children suffering from acute Iymphoblastic leukemia. Indian J Pediatr 1995; 62: 737-741.

86. Spicka I, Hajek R, Gregora E etal. The first results with the thal idomide treatment in the Czech Republic. Klinicka Onkologie 2002; 15: 42-43.

87. TillerJW, Ekert $\mathrm{H}$, Rickards WS. Family reactions in childhood acute lymphoblastic leukaemia in remission. Aust PaediatrJ 1977; 13: 176-181.

88. Verga L, Miccolis I, Rossini F et al. Home care project in neutropenic hematologic patients in the Monza area: Two year activity. Haematologica 2009; 94: 182.

89. Webert KE, Cook RJ, Couban S et al. A study of the agreement between patient self-assessment and study personnel assessment of bleeding symptoms. Transfusion 2006; 46: 1926-1933.

90. Williams PD, Piamjariyakul U, Ducey K et al. Cancer Treatment, Symptom Monitoring, and Self-care in Adults: Pilot Study. Cancer nursing 2006; 29: 347-355.

91. Yogaparan T, Panju A, Minden M et al. Information needs of adult patients 50 or older with newly diagnosed acute myeloid leukemia. Leukemia Research 2009; 33: 1288-1290.

92. Ahles TA, Saykin AJ, Furstenberg CT et al. Quality of Life of Long-Term Survivors of Breast Cancer and Lymphoma Treated With Standard-Dose Chemotherapy or Local Therapy. Journal of Clinical Oncology 2005; 23: 4399-4405.

93. Alexander SC, Sullivan AM, Back AL et al. Information giving and receiving in hematological malignancy consultations. Psycho-oncology 2012; 21: 297-306. 
94. Altmaier EM, Gingrich RD, Fyfe MA. Two-year adjustment of bone marrow transplant survivors. Bone Marrow Transplantation 1991; 7: 311-316.

95. Andrykowski MA, Brady MJ, Henslee-Downey PJ. Psychosocial factors predictive of survival after allogeneic bone marrow transplantation for leukemia. Psychosom Med 1994; 56: 432-439.

96. Arden-Close E, Absolom K, Greenfield DMet al. Gender differences in self-reported late effects, quality of life and satisfaction with clinic in survivors of lymphoma. Psycho-oncology 2011; 20: 12021210.

97. Arnan M, Alonso E, Tienda R et al. Independent impact of transfusion dependency and iron overload on survival of patients with myelodisplastic syndromes. Haematologica 1995; 95: 126-127.

98. Aviles A, Duque G, Talavera A, Guzman R. Interferon al pha 2b as maintenance therapy in low grade malignant lymphoma improves duration of remission and survival. Leukemia \& Lymphoma 1996; 20: 495-499.

99. Bajenova P, Lomaia E, Zaritskey A, Schelkova O. Psychological profile of chronic myelogenous leukemia (CML) patients. Haematologica 2010; 95: 543-544.

100. Baker KS, Ness KK, Weisdorf Detal. Late effects in survivors of acute leukemia treated with hematopoietic cell transplantation: a report from the Bone Marrow Transplant Survivor Study. Leukemia 2010; 24: 2039-2047.

101. Balderas-Pea L-MA, Sat-Muoz D, Contreras-Hernandez I et al. Analysis if the satisfaction with health care through the EORTC IN-PATSAT32 questionnaire among patients with breast cancer, nonHodgkin lymphoma and colorectal cancer in different stages. Relationship with the sociodemographic characterisitcs, comorbidity states, and care process variables in the Mexican Institute of Social Security. Value Health 2011; 14: S96-S99.

102. Barr RD, Silva A, Wong M et al. A comparative assessment of attendance and nonattendance at Camp Trillium by children with cancer and their families; including their utilization of health and social services. Journal of Pediatric Hematology/Oncology 2010; 32: 358-365.

103. Barrera M, Atenafu E. Cognitive, educational, psychosocial adjustment and quality of life of children who survive hematopoietic SCT and their siblings. Bone Marrow Transplant 2008; 42: 15-21.

104. Bauld C, Anderson V, Arnold J. Psychosocial aspects of adolescent cancer survival. Journal of Paediatrics and Child Health 1998; 34: 120-126.

105. Beanlands HJ, Lipton JH, McCay EA et al. Self-concept as a "BMT patient", illness intrusiveness, and engulfment in allogeneic bone marrow transplant recipients. J Psychosom Res 2003; 55: 419-425. 
106. Bertero C, Ek A-C. Quality of life of adults with acute leukaemia. Journal of Advanced Nursing 1993; 18: $1346-1353$

107. Bertero C, Eriksson BE, Ek A-C. Explaining different profiles in quality of life experiences in acute and chronicleukemia. Cancer Nursing 1997; 20: 100-104.

108. Bertero C, Eriksson BE, Ek AC. A substantive theory of quality of life of adults with chronic leukaemia. Int J Nurs Stud 1997; 34: 9-16.

109. Black EK, White CA. Fear of recurrence, sense of coherence and posttraumatic stress disorder in hae matological cancer survivors. Psycho-Oncology 2005; 14: 510-515.

110. Booker R, Olson K, Pilarski LM et al. The relationships among physiologic variables, quality of life, and fatigue in patients with multiple myeloma. Oncol Nurs Forum 2009; 36: 209-216.

111. Bulsara C, Ward A, Joske D. Haematological cancer patients: achieving a sense of empowerment by use of strategies to control illness. Journal of Clinical Nursing 2004; 13: 251-258.

112. Calaminus G, Weinspach S, Teske C, Gobel U. Quality of survival in children and adolescents after treatment for childhood cancer: the influence of reported late effects on health related quality of life. Klin Padiatr 2007; 219: 152-157.

113. Caocci G, Pisano V, Vacca A et al. Health-related quality of life assessment during high-dose chemotherapy and stem cell transplantation in patients with haematologic malignancies. In EBMT 2011, Edition 2011; S172-173.

114. Cavusoglu H. Problems related to the diagnosis and treatment of adolescents with leukemia. Issues ComprPediatr Nurs 2000; 23: 15-26.

115. Cella D, Beaumont J, Webster K etal. Measuring the concerns of cancer patients with low platelet counts: the Functional Assessment of Cancer Therapy-Thrombocytopenia (FACT-Th) questionnaire. Supportive Care in Cancer 2006; 14: 1220-1231.

116. Cella DF, Tross S. Psychological adjustment to survival from Hodgkin's disease. J Consult Clin Psychol 1986; 54: 616-622.

117. Chang G, Orav EJ, McNamara TK et al. Psychosocial function after hematopoietic stem cell transplantation. Psychosomatics 2005; 46: 34-40.

118. Chao C-C, Chen S-H, Wang C-Y et al. Psychosocial adjustment among pediatric cancer patients and their parents. Psychiatry and Clinical Neurosciences 2003; 57: 75-81.

119. Chen RC, Royce TJ, Extermann M, Reeve BB. Impact of age and comorbidity on treatment and outcomes in elderly cancer patients. Semin Radiat Oncol 2012; 22: 265-271. 
120. Chou L-N, Hunter A. Factors affecting quality of life in Taiwanese survivors of childhood cancer. Journal of Advanced Nursing 2009; 65: 2131-2141.

121. Claessens JJM, Beerendonk CCM, Schattenberg AVMB. Quality of life, reproduction and sexuality after stem cell transplantation with partially T-cell-depleted grafts and after conditioning with a regimen including total body irradiation. Bone Marrow Transplant 2006; 37: 831-836.

122. Clunies-Ross C, Lansdown R. Concepts of death, illness and isolation found in children with leukaemia. Child: Care, Health and Development 1988; 14: 373-386.

123. Cocks K, Cohen D, Wisl $\varnothing f f F$ etal. An international field study of the reliability and validity of a disease-specific questionnaire module (the QLQ-MY20) in assessing the quality of life of patients with multiple myeloma. European Journal of Cancer 2007; 43: 1670-1678.

124. Cole B, Broer K, Hopkins Cet al. A Randomized Controlled Trial of Spiritually-Focused Meditation In Patients Newly Diagnosed with Acute Leukemia. ASH Annual Meeting Abstracts 2010; 116: 1519-.

125. Cong Z, Ireland A, Stull D et al. Patients experience with treatments of chemotherapy induced anemia (CIA) and myelodysplastic syndromes (MDS). European Journal of Cancer 2009; 7: 199-200.

126. Cortes JE, Mauro MJ, Goldberg SL et al. Quality of Life During Early Tyrosine Kinase Inhibitor Treatment As Self-Reported by Chronic Myeloid Leukemia Patients Participating in a Prospective Observational Study (SIMPLICITY). ASH Annual Meeting Abstracts 2011; 118: 4435-.

127. Cousson-Gelie F, Allart P, Soubeyran P et al. Determinants and changes in psychological adaptation and quality of life during chemotherapy for diffuse large B cell non-hodgkin's lymhpmoa in the vulnerable and frail elderly. In IPOS 12th World Congress of Psycho-Oncology, Edition Quebec City: Psycho-Oncology 2010.

128. Dahan JF, Auerbach CF. A qualitative study of the trauma and posttraumatic growth of multiple myeloma patients treated with peripheral blood stem cell transplant. Palliat Support Care 2006; 4: 365-387.

129. Daiter S, Larson RA, Weddington WW, Ultmann JE. Psychosocial symptomatology, personal growth, and development among young adult patients following the diagnosis of leukemia or lymphoma. Journal of Clinical Oncology 1988; 6: 613-617.

130. DanhauerSC, Tooze JA, Holder P et al. Healing touch as a supportive intervention for adult acute leukemia patients: a pilot investigation of effects on distress and symptoms. J Soc Int egr Oncol 2008; 6: 89-97. 
131. DanhauerSC, Vishnevsky T, Campbell CR et al. Music for patients with hematological malignancies undergoing bone marrow biopsy: A randomized controlled study of anxiety, perceived pain, and patient satisfaction. Journal of the Society for Integrative Oncology 2010; 8: 140-147.

132. Davies J, Leach M, Meiklejohn D et al. Population preferences for treatment outcomes in chronic Iymphocyticleukemia. Value in Health 2009; 12.

133. DeFor TE, Burns LJ, Gold EM, Weisdorf DJ. A randomized trial of the effect of a walking regimen on the functional status of 100 adult allogeneic donor hematopoietic cell transplant patients. Biology of Blood and Marrow Transplantation 2007; 13: 948-955.

134. Demakos E, Kurtin S. Disease burden and treatment impact associated with myelodysplastic syndromes: Initial estimates. Leukemia Research 2011; 35: S142.

135. Demierre M-F, Gan S, Jones J, Miller DR. Significant impact of cutaneous T-cell lymphoma on patients' quality of life. Cancer 2006; 107: 2504-2511.

136. Demierre MF, Tien A, Miller D. Health-related quality-of-life assessment in patients with cutaneous T-cell lymphoma. Archives of Dermatology 2005; 141: 325-330.

137. Dowling JS, Hockenberry M, Gregory RL. Sense of humor, childhood cancer stre ssors, and outcomes of psychosocial adjustment, immune function, and infection. J Pediatr Oncol Nurs 2003; 20: 271292.

138. Dreifuss E, Meerwein F. [Concept of the double as a problem of relationships in problems of leukemia and terminal cancer patients and its appearance in art therapy]. Z Psychosom Med Psychoanal 1984; 30: 282-291.

139. Dubois D, Dhawan R, van de Velde Hetal. Descriptive and Prognostic Value of Patient-Reported Outcomes: The Bortezomib Experience in Relapsed and Refractory Multiple Mye loma. Journal of Clinical Oncology 2006; 24: 976-982.

140. Duffy TP. When to let go. New England Journal of Medicine 1992; 326: 933-935.

141. Efficace F, Breccia M, Saussele S et al. Which health-related quality of life aspects are important to patients with chronic myeloid leukemia receiving targeted therapies and to health care professionals? Annals of Hematology 2012; 91: 1371-1381.

142. Efficace F, Gaidano G, Stauder R et al. Health-related qual ity of life profile and request of prognostic information on survival at the time of diagnosis in patients with high-risk myelodysplastic syndromes. Blood 2011; 118: Abstract.

143. ElmbergerE, Bolund C, Lutzen K. Men with cancer. Changes in attempts to master the self-image as a man and as a parent. Cancer Nurs 2002; 25: 477-485.

Quality of life and bleeding 
144. ElmbergerE, Bolund C, Lutzen K. Experience of dealing with moral responsibility as a mother with cancer. Nurs Ethics 2005; 12: 253-262.

145. Else M, Smith AG, Cocks K et al. Patients' experience of chronic lymphocytic leukaemia: baseline health-related quality of life results from the LRF CLL4 trial. British Journal of Haematology 2008; 143: 690-697.

146. Ernst J, Brähler E, Aldaoud A et al. Desired and perceived participation in medical decision-making in patients with haemato-oncological diseases. Leukemia Research 2010; 34: 390-392.

147. Evans DR, Thompson AB, Browne GB et al. Factors associated with the psychological well-being of adults with acute leukemia in remission. Journal of Clinical Psychology 1993; 49: 153-160.

148. Farsi Z, Dehghan Nayeri N, Negarandeh R. Coping strategies of adults with leukemia undergoing hematopoietic stem cell transplantation in Iran: a qualitativestudy. Nursing \& Health Sciences 2010; 12: 485-492.

149. Fisman N, D'Agnese de Gonzalez Victorica MI. [Patient and family attitudes in hemophilia and leukemia]. Medicina (B Aires) 1981; 41 Suppl: 282-286.

150. Forbriger A. [Living with a hematologic-oncologicillness: information from person to person gives strength]. Pflege Z2003; 56: 788-790.

151. Forjaz MJ, Guarnaccia CA. Hematological cancer patients' quality of life: self versus intimate or nonintimate confidant reports. Psychooncology 1999; 8: 546-552.

152. Forjaz MJ, Guarnaccia CA. A comparison of Portuguese and American patients with hematological malignancies: a cross-cultural survey of health-related quality of life. Psychooncology 2001; 10: 251258.

153. Franiczek W, Sonta-Jakimczyk D, Koehler M, Kempa M. [The emotional state of children with Iymphoblasticleukemia]. Wiad Lek 1984; 37: 511-515.

154. Franiczek W, Sonta-Jakimczyk D, Sroczynska M. [Psychological examination of children with Iymphoblasticleukemia]. Wiad Lek 1980; 33: 1277-1281.

155. Frick E, Borasio GD, Zehentner H et al. Individual quality of life of patients undergoing autologous peripheral blood stem cell transplantation. Psycho-Oncology 2004; 13: 116-124.

156. Friis LS, Elverdam B, Schmidt KG. The patient's perspective: a qualitative study of acute myeloid leukaemia patients' need for information and their information-seeking behaviour. Supportive Care in Cancer 2003; 11: 162-170.

157. Friis LS, Elverdam B, Schmidt KG. [Need of and searching for information by patients with acute myeloid leukemia undergoing intensive therapy]. Ugeskr Laeger 2005; 167: 514-516. 
158. Fritzsche K, Struss Y, Stein B, Spahn C. Psychosomaticliaison service in hematological oncology: need for psychotherapeutic interventions and their realization. Hematol Oncol 2003; 21: 83-89.

159. Fritzsche K, Struss Y, Hammel A et al. Relationship between psychosocial distress, treatment need and use of psychotherapeutic interventions within a psychosomatic liaison service in hematological oncology. Onkologie 2004; 27: 457-461.

160. Gariepy N, Howe N. The therapeutic power of play: examining the play of young children with leukaemia. Child Care Health Dev 2003; 29: 523-537.

161. Gaston-Johansson F, Franco T, Zimmerman L. Pain and psychological distress in patients undergoing autologous bone marrow transplantation. Oncology Nursing Forum 1992; 19: 41-48.

162. Goldberg S, Bollu VK, Morlock R et al. Association between chronic myeloid leukemia (CML) treatment responses and patient staisfaction, functioning and quality of life (QOL): Patient survey results. Journal of Clinical Oncology 2011; 29: Abstract.

163. Gupta V, Panzarella T, Li L et al. A prospective comparison of outcomes and resource utilization in patients with myeloid malignancies undergoing Allogeneic Hematopoietic Cell Transplantation (ALLOHCT) using myeloablative or reduced intensity conditioning. Biology of Bl ood and Marrow Transplantation 2010; 16: S270.

164. Haag R, Graf N, Jost W. [Subjectively experienced anxiety as an aspect of coping with illness in children with malignant diseases]. Prax Kinderpsychol Kinderpsychiatr 1991; 40: 78-84.

165. Hacker ED, Larson JL, Peace D. Exercise in patients receiving hematopoietic stem cell transplantation: lessons learned and results from a feasibility study. Oncology Nursing Forum 2011; 38: 216-223.

166. Han J, Liu JE, Xiao Q et al. The experiences and feelings of Ch inese children living with leukemia: a qualitative study. Cancer Nursing 2011; 34: 134-141.

167. Harrer ME, Mosheim R, Richter R et al. [Coping and life satisfaction in patients with Hodgkin's disease in remission. A contribution to the question of adaptive aspects of coping processes]. Psychother Psychosom Med Psychol 1993; 43: 121-132.

168. Heinonen $\mathrm{H}$, Volin L, Uutela A et al. Quality of life and factors related to perceived satisfaction with quality of life after allogeneic bone marrow transplantation. Annals of Hematology 2001; 80: $137-$ 143.

169. HenkerFO, Haut A, Brown DA. Leukemia remission--effect on psychic adjustment. J Ark Med Soc 1980; 76: 491-493. 
170. Heptinstall K. Quality of life in myelodysplastic syndromes. A special report from the Myelodysplastic Syndromes Foundation, Inc. Oncology (Williston Park) 2008; 22: 13-18; discussion 19.

171. Hinds PS, Billups CA, Cao X et al. Health-related quality of life in adolescents at the time of diagnosis with osteosarcoma or acute myeloid leukemia. Eur J Oncol Nurs 2009; 13: 156-163.

172. Hjermstad MJ, Evensen SA, Kvaloy SO et al. The CARES-SF used for prospective assessment of health-related quality of life after stem cell transplantation. Psycho-oncology 2003; 12: 803-813.

173. Hjermstad MJ, Knobel H, Brinch L et al. A prospective study of health-related quality of life, fatigue, anxiety and depression 3-5years after stem cell transplantation. Bone Marrow Transplantation 2004; 34: 257-266.

174. Hoff L, Tidefelt U, Thaning L, Hermeren G. In the shadow of bad news - views of patients with acute leukaemia, myeloma or lung cancer about information, from diagnosis to cure or death. BMC Palliat Care 2007; 6: 1 .

175. Hofmann S, Tuchler H, Bernhart M et al. [A questionnaire suitable for general practice for detection of the health status and quality of life of patients with hemato-oncologic diseases: psychometric properties. The Study G "Quality of Life" of the International Society for Chemo - and Immunotherapy (I.G.C.I.)]. Wien Klin Wochenschr 1993; 105: 277-283.

176. Holzner B, Kemmler G, Kopp M et al. Quality of life of patients with chronic lymphocytic leu kemia: results of a longitudinal investigation over 1 yr. European Journal of Haematology 2004; 72: 381389.

177. Howell DA, Smith AG, Roman E. Help-seeking behaviour in patients with lymphoma. European Journal of Cancer Care 2008; 17: 394-403.

178. Hsu C, Wang J-D, Hwang J-S et al. Survival-weighted health profile for long-term survivors of acute myelogenous leukemia. Quality of Life Research 2003; 12: 503-517.

179. Itzykson R, Ayari S, Vassilief $D$ et al. Is there a role for all-trans retinoic acid in combination with recombinant erythropoetin in myelodysplastic syndromes? A report on 59 cases. Leukemia 2009; 23: 673-678.

180. Jenkins PL, Lester H, AlexanderJ, Whittaker J. A prospective study of psychosocial morbidity in adult bone marrow transplant recipients. Psychosomatics 1994; 35: 361-367.

181. Johansson E, Wilson B, Brunton Let al. Symptoms Before, During, and 14 Months After the Beginning of Treatment as Perceived by Patients With Lymphoma. Oncology Nursing Forum 2010; 37: E105-E113. 
182. Kaiser A, Makowska H, Haus O et al. [Psychological problems of patients with acute and chronic leukemia]. Polskie Archiwum Medycyny Wewnetrznej 1982; 68: 205-213.

183. Kazak AE, Barakat LP. Brief Report: Parenting Stress and Quality of Life During Treatment for Childhood Leukemia Predicts Child and Parent Adjustment After Treatment Ends. Journal of Pediatric Psychology 1997; 22: 749-758.

184. Khalafallah AA, McDonnell K, Dawar HU et al. Quality of life assessment in mutiple myeloma patients endergoing dose-reduced tandem autologous stem cell transplantation. Mediterranean Journal of Hematology and Infectious Diseases 2011; 3: e2011057.

185. Klepin HD, DanhauerSC, Tooze JA et al. Exercise for older adult inpatients with acute myelogenous leukemia: A pilot study. Journal of Geriatric Oncology 2011; 2: 11-17.

186. Kluin-Nelemans HC, Buck G, le Cessie S et al. Randomized comparison of low-dose versus high-dose interferon-alfa in chronic myeloid leukemia: prospective collaboration of 3 joint trials by the MRC and HOVON groups. Blood 2004; 103: 4408-4415.

187. Koehler K, Dogan E, Koehler Met al. [Surviving the initial phase: subjectivetheories of illness in patients suffering from acute leukaemia at the end of initial inpatient treatment]. Z Psychosom Med Psychother 2011; 57: 141-156.

188. Koehler M, Koehler K, Koenigsmann Met al. Beyond diagnosis: subjective theories of illness in adult patients with acute myeloid leukemia. Hematology 2011; 16: 5-13.

189. Koenigsmann M, Koehler K, Regner A etal. Facing mortality: A qua litative in-depth interview study on illness perception, lay theories and coping strategies of adult patients with acute leukemia 1 week after diagnosis. Leukemia Research 2006; 30: 1127-1134.

190. Kohle K. [Emotional status in the decision process]. Verhandlungen der Deutschen Gesellschaft fur Innere Medizin 1986; 92: 452-454.

191. Kohler K, Regner A, Koenigsmann Met al. [IIIness perceptions of patients suffering from acute leukaemia one week after diagnosis]. Z Psychosom Med Psychother 2005; 51: 388-402.

192. Kornblith AB, Anderson J, Cella DF et al. Quality of life assessment of Hodgkin's disease survivors: a model for cooperative clinical trials. Oncology (Williston Park) 1990; 4: 93-101; discussion 104.

193. Kuczynski E, Silva CA, Cristofani LMet al. [Quality of life evaluation in children and adolescents with chronic and/or incapacitating diseases: a Brazilian study]. An Pediatr (Barc) 2003; 58: 550-555.

194. Kupst MJ, Schulman JL. Long-Term Coping with Pediatric Leukemia: A Six-Year Follow-Up Study. Journal of Pediatric Psychology 1988; 13: 7-22. 
195. Kupst MJ, Tylke L, Thomas L et al. Strategies of Intervention with Families of Pediatric Leukemia Patients. Social Work in Health Care 1983; 8: 31-47.

196. Landolt M, Vollrath M, Niggli F et al. Health-related quality of life in children with newly diagnosed cancer: a one year follow-up study. Health and Quality of Life Outcomes 2006; 4.

197. Lee SJ, Sullivan A, Goldman RE et al. Content of Hematologic Malignancies Consultations: Good and Bad News From the HEMA-COMM Study. ASH Annual Meeting Abstracts 2009; 114: 68-.

198. Levin TT, Riskind J, Li Y. Looming cognitive style and quality of life in a cancer cohort. Palliative \& Supportive Care 2010; 8: 449-454.

199. Lim J-w, Zebrack B. Social networks and quality of life for long-term survivors of leukemia and Iymphoma. Supportive Care in Cancer 2006; 14: 185-192.

200. Lin W-Y, Lai Y-R, Ma J et al. Assessment of quality of life in patients with hematological tumor after hematopoietic stem cell transplantation. Journal of Clinical Rehabilitative Tissue Engineering Research 2007; 11: 8478-8482.

201. Littlewood TJ, Kallich JD, San Miguel J et al. Efficacy of Darbepoetin Alfa in Alleviating Fatigue and the Effect of Fatigue on Quality of Life in Anemic Patie nts with Lymphoproliferative Malignancies. Journal of Pain and Symptom Management 2006; 31: 317-325.

202. Lobb EA, Joske D, Butow P et al. When the safety net of treatment has been removed: Patients' unmet needs at the completion of treatment for haematological malignancies. Patient Education and Counseling 2009; 77: 103-108.

203. Loge JH, Abrahamsen AF, Ekeberg $\varnothing$, Kaasa S. Reduced health-related quality of life among Hodgkin's disease survivors: A comparative study with general population norms. Annals of Oncology 1999; 10: 71-77.

204. Love RR, Leventhal H, Easterling DV, Nerenz DR. Side effects and emotional distress during cancer chemotherapy. Cancer 1989; 63: 604-612.

205. Lübbert M, Suciu S, Baila L et al. Low-Dose Decitabine Versus Best Supportive Care in Elderly Patients With Intermediate- or High-Risk Myelodysplastic Syndrome (MDS) Ineligible for Intensive Chemotherapy: Final Results of the Randomized Phase III Study of the European Organisation for Research and Treatment of Cancer Leukemia Group and the German MDS Study Group. Journal of Clinical Oncology 2011; 29: 1987-1996.

206. Ludwig H, Viterbo L, Greil R etal. Phase II study of bortezomib, thalidomide, and dexamethasone +/cyclophosphamide as induction therapy in previously untreated multiple myeloma (MM): Safety and activity including evaluation of MRD. Haematologica 2010; 95: 149-150.

Quality of life and bleeding 
207. Maher K, De Vries K. An exploration of the lived experiences of individuals with relapsed Multiple Myeloma. European Journal of Cancer Care 2011; 20: 267-275.

208. Maurice-Stam H, Silberbusch LM, Last BF, Grootenhuis MA. Evaluation of a psycho-educational group intervention for children treated for cancer: a descriptive pilot study. Psycho-Oncology 2009; 18: 762-766.

209. McDonald G. Myeloproliferative disorder therapy: assessment and management of adverse events-a psychiatrist's perspective. Hematological Oncology 2009; 27: 14-16.

210. McGrath P. Findings from an Educational Support Course for Patients with Leukemia. Cancer Practice 1999; 7: 198-204.

211. McGrath P. Taking Control: findings of a prospective study of an educational course for patients with leukaemia. Supportive Care in Cancer 2000; 8: 377-384.

212. McGrath P, Leahy M. Catastrophic bleeds during end-of-life care in haematology: controversies from Australian research. Supportive Care in Cancer 2009; 17: 527-537.

213. McGrath P, Paton MA, Huff N. Beginning treatment for paediatric acute myeloid leukaemia: diagnosis and the early hospital experience. Scandinavian Journal of Caring Sciences 2004; 18: 358367.

214. McGrath P, Paton MA, Huff N. Beginning Treatment for Pediatric Acute Myeloid Leukemia: The Family Connection. Issues in Comprehensive Pediatric Nursing 2005; 28: 97-114.

215. McGrath P, Suppiah R, Patton MA. Re-entering life: paediatric acute myeloid leukaemia at one year post treatment. Aust J Holist Nurs 2005; 12: 23-34.

216. Meenaghan T, Dowling M. Treatment for acute leukaemia: elderly patients' lived experiences. Br J Nurs 2010; 19: 52-57.

217. Mesa RA, Niblack J, Wadleigh M etal. The burden of fatigue and quality of life in myeloproliferative disorders (MPDs). Cancer 2007; 109: 68-76.

218. Mesa RA, Rey J, Tefferi A et al. Fatigue and Daily Life in Patients with Essential Thrombocythemia: Comparisons Between the USA and France in 447 Patients. ASH Annual Meeting Abstracts 2009; 114: 2904-.

219. Miano M, Manfredini L, Garaventa A et al. Home care for children following haematopoietic stem cell transplantation. Bone Marrow Transplant 2003; 31: 607-610.

220. Mohamedali HZ, Breunis H, Panju A, Alibhai SMH. Information needs, decisional regret and satisfaction of older and younger adults with acute myeloid leukemia. Journal of Geriatric Oncology 2010; 1: 66-72.

Quality of life and bleeding 
221. Molassiotis. A correlational evaluation of tiredness and lack of energy in survivors of haematological malignancies. European Journal of Cancer Care 1999; 8: 19-25.

222. Molassiotis A, Morris P. The meaning of quality of life and the effects of unrelated donor bone marrow transplants for chronic myeloid leukemia in adult long-term survivors. Cancer Nursing 1998; 21: 205-211.

223. Molassiotis A, Morris P. Quality of life in patients with chronic myeloid leukemia after unrelated donor bone marrow transplantation. Cancer Nursing 1999; 22: 340-349.

224. Molassiotis A, Van den Akker OBA, Milligan DW, Goldman JM. Symptom distress, coping style and biological variables as predictors of survival after bone marrow transplantation. Journal of Psychosomatic Research 1997; 42: 275-285.

225. Molica S. Quality of life in chronic lymphocytic le uke mia: a neglected issue. Leukemia \& Lymphoma 2005; 46: 1709-1714.

226. Montgomery C, Pocock M, Titley K, Lloyd K. Individual quality of life in patients with leukaemia and Iymphoma. Psycho-Oncology 2002; 11: 239-243.

227. Montgomery C, Pocock M, Titley K, Lloyd K. Predicting psychological distress in patients with leukaemia and lymphoma. Journal of Psychosomatic Research 2003; 54: 289-292.

228. Morrow GR, Chiarello RJ, Derogatis LR. A new scale for assessing patients' psychosocial adjustment to medical illness. Psychological Medicine 1978; 8: 605-610.

229. Mühlbacher A, Nübling M. Analysis of physicians' perspectives versus patients' preferences: direct assessment and discrete choice experiments in the therapy of multiple myeloma. The European Journal of Health Economics 2011; 12: 193-203.

230. Mulhern RK, Crisco JJ, Camitta BM. Patterns of communication among pediatric patients with leukemia, parents, and physicians: Prognostic disagreements and misunderstandings. The Journal of Pediatrics 1981; 99: 480-483.

231. Munet-Vilaro F, Vessey JA. Children's explanation of leukemia: a Hispanic perspective. J Pediatr Nurs 1990; 5: 274-282.

232. Nerenz DR, Leventhal H, Love RR. Factors contributing to emotional distress during cancer chemotherapy. Cancer 1982; 50: 1020-1027.

233. Nes L, Ehlers S, Gastineau D. Self-regulatory fatigue in haemtologic malignancies: Impact on quality of life, coping and adherence. Psycho-Oncology 2010; 19: S91-92.

234. Neuser J. [Psychosomatic research on stress in bone marrow transplantation]. Psychother Psychosom Med Psychol 1990; 40: 136-142.

Quality of life and bleeding 
235. Oliva E, Aloe Spiriti M, Poloni A et al. P077 Adaptation and changes in quality of life in patients with myelodysplastic syndrome. Leukemia Research 2009; 33, Supplement 1: S103.

236. Oliva EN, Nobile F, Alimena G et al. Quality of life in elderly patients with acute myeloid leukemia: patients may be more accurate than physicians. Haematologica 2011; 96: 696-702.

237. Oliva EN, Finelli C, Santini Vet al. Quality of life and physicians' perception in myelodysplastic syndromes. American Journal of Blood Research 2012; 2: 136-147.

238. Park JE, Kim KI, Yoon SS et al. Psychological distress as a negative survival factor for patients with hematologic malignancies who underwent allogeneic hematopoietic stem cell transplantation. Pharmacotherapy 2010; 30: 1239-1246.

239. Parry C, Morningstar E, Kendall J, Coleman EA. Working Without a Net: Leukemia and Lymphoma Survivors' Perspectives on Care Delivery at End-of-Treatment and Beyond. Journal of Psychosocial Oncology 2011; 29: 175-198.

240. Peeters J, Meitert J, Paulides M et al. Health-related quality of life (HRQL) in all-patients treated with chemotherapy only: a report from the late effects surveill ance system in Germany. Klin Padiatr 2009; 221: 156-161.

241. Persson L, Hallberg IR. Lived experience of survivors of leukemia or malignant lymphoma. Cancer Nursing 2004; 27: 303-313.

242. Pestereva EV, Chulkova VA, Il'in NV, Simonova ON. [Role of anosognosia in development of attitude toward Hodgkin's disease]. Vopr Onkol 2008; 54: 360-364.

243. Petal MJ, Sinha BK, Shah PM et al. Patterns of psychological disturbance among leukemia patients and their relatives. Indian J Cancer 1987; 24: 264-271.

244. Potrata B, Cavet J, BlairS et al. Understanding distress and distressing experiences in patients living with multiple myeloma: an exploratory study. Psycho-Oncology 2011; 20: 127-134.

245. Pound CM, Clark C, Ni A et al. Corticosteroids, Behavior, and Quality of Life in Children Treated for Acute Lymphoblastic Leukemia; A Multicentered Trial. Journal of Pediatric Hematology/Oncology 2012; 34: 517-523.

246. Quan Le R, Bevans M, Savani BN et al. Favorable outcomes in patients surviving 5 or more years after allogeneic hematopoietic stem cell transplantation for hematologic malignancies. Biology of Blood and Marrow Transplantation 2010; 16: 1162-1170.

247. Quan Le R, Bevans M, Savani BN et al. Favorable Outcome and Quality of Life in Patients Surviving 5 or More Years After Allogeneic Hematopoietic Stem Cell Transplantation for Hematologic Malignancies. ASH Annual Meeting Abstracts 2009; 114: 3312-. 
248. Robak T, Dmoszynska A, Solal-Céligny P et al. Rituximab Plus Fludarabine and Cyclophosphamide Prolongs Progression-Free Survival Compared With Fludarabine and Cyclophosphamide Alone in Previously Treated Chronic Lymphocytic Leukemia. Journal of Clinical Oncology 2010; 28: 17561765.

249. Ruan J, Martin P, Coleman M et al. Durable responses with the metronomic rituximab and thalidomide plus prednisone, etoposide, procarbazine, and cyclophosphamide regimen in elderly patients with recurrent mantle cell lymphoma. Cancer 2010; 116: 2655-2664.

250. Rusiewicz A, DuHamel KN, Burkhalter J et al. Psychological distress in long-term survivors of hematopoietic stem cell transplantation. Psycho-Oncology 2008; 17: 329-337.

251. Samuelsson J, Hasselbalch $H$, Bruserud $O$ et al. A phase II trial of pegylated interferon $\alpha-2 b$ therapy for polycythemia vera and essential thrombocythemia. Cancer 2006; 106: 2397-2405.

252. San Juan AF, Chamorro-Vina C, Mate-Munoz JL et al. Functional capacity of children with leukemia. Int J Sports Med 2008; 29: 163-167.

253. San Juan AF, Chamorro-Vina C, Moral S et al. Benefits of intrahospital exercise training after pediatric bone marrow transplantation. Int J Sports Med 2008; 29: 439-446.

254. Sanders JB, Kardinal CG. Adaptive Coping Mechanisms in Adult Acute Leukemia Patients in Remission. JAMA: The Journal of the American Medical Association 1977; 238: 952-954.

255. Santos FRM, Kozasa EH, Chauffaille MdLLF et al. Psychosocial adaptation and quality of life among Brazilian patients with different hematological malignancies. Journal of Psychosomatic Research 2006; 60: 505-511.

256. Schumacher A. [Quality of life in patients with acute myeloid leukemia]. Medizinische Klinik (Munich) 1994; 89: 410-415.

257. Schumacher A, Kessler T, Riedel A et al. [Quality of life and coping with illness in patients with acute myeloid leukemia]. Psychother Psychosom Med Psychol 1996; 46: 385-390.

258. Sekeres M. 32 Patient-doctor relationship-perceptions. Leukemia Research 2011; 35, Supplement 1: S11.

259. Sekeres MA, Maciejewski JP, List AF et al. Perceptions of Disease State, Treatment Expectations, and Prognosis Among Patients with Myelodysplastic Syndromes. ASH Annual Meeting Abstracts 2009; 114: $1771-$

260. Shanafelt TD, Bowen D, Venkat C etal. Quality of life in chronic lymphocytic leukemia: an international survey of 1482 patients. British Journal of Haematology 2007; 139: 255-264. 
261. Shanafelt TD, Bowen DA, Venkat Cet al. The physician-patient relationship and quality of life: Lessons from chronic lymphocytic leukemia. Leukemia Research 2009; 33: 263-270.

262. Sharan P, Mehta M, Chaudhry V. Coping and adaptation in acute Iymphoblasticleukem ia. Indian Journal of Pediatrics 1995; 62: 467-471.

263. Sherman A, Simonton S, Latif U et al. Religious Struggle and Religious Comfort in Response to Illness: Health Outcomes among Stem Cell Transplant Patients. Journal of Behavioral Medicine 2005; 28: 359-367.

264. Sherman AC, Coleman EA, Griffith K et al. Use of a supportive care team for screening and preemptive intervention among multiple myeloma patients receiving stem cell transplantation. Supportive Care in Cancer 2003; 11: 568-574.

265. Sherman AC, Simonton S, Latif U et al. Psychosocial adjustment and quality of life among multiple myeloma patients undergoing evaluation for autologous stem cell transplantation. Bone Marrow Transplant 2004; 33: 955-962.

266. Sherman AC, Simonton S, Latif $U$ et al. Changes in quality-of-life and psychosocial adjustment among multiple myeloma patients treated with high-dose melphalan and autologous stem cell transplantation. Biology of Blood and Marrow Transplantation 2009; 15: 12-20.

267. Slovacek L, Slovackova B, Jebavy L. Global quality of life in patients who have undergone the hematopoietic stem cell transplantation: finding from transversal and retrospective study. Exp Oncol 2005; 27: 238-242.

268. Smith AG, Soutar RL, Schey S et al. Home care versus hospital care in patients with multiple myeloma treated with pamidronate International Journal of Palliative Nursing 2004; 10: 144-149.

269. Smith BD. Myelodysplastic Syndromes: Challenges to Improving Patient and Caregiver Satisfaction. The American Journal of Medicine 2012; 125: S26-S30.

270. So WKW, Dodgson J, Tai JWM. Fatigue and Quality of Life Among Chinese Patients With Hematologic Malignancy After Bone Marrow Transplantation. Cancer Nursing 2003; 26: 211-219.

271. Stalfelt AM, Brodin H, Pettersson S, Eklöf A. The final phase in acute myeloid leukaemia (AML): A study on bleeding, infection and pain. Leukemia Research 2003; 27: 481-488.

272. Stalfelt AM, Wadman B. Assessing quality of life in leukemia: presentation of an instrument for assessing quality of life in patients with blood malignancies. Qual Assur Health Care 1993; 5: 201211.

273. Steeves RH. Patients who have undergone bone marrow transplantation: their quest for meaning. Oncology Nursing Forum 1992; 19: 899-905. 
274. Strasser-Weippl K, Ludwig H. Psychosocial QOL is an independent predictor of overall survival in newly diagnosed patients with multiple myeloma. European Journal of Haematology 2008; 81: 374379.

275. Stringer J, Swindell R, Dennis M. Massage in patients undergoing intensive chemotherapy reduces serum cortisol and prolactin. Psycho-Oncology 2008; 17: 1024-1031.

276. Tschuschke V, Hertenstein B, Arnold R et al. Associations between coping and survival time of adult leukemia patients receiving allogeneic bone marrow transplantation: Results of a prospective study. Journal of Psychosomatic Research 2001; 50: 277-285.

277. TurnerS, Maher EJ, Young T et al. What are the information priorities for cancer patients involved in treatment decisions? An experienced surrogate study in Hodgkin's disease. Br J Cancer 1996; 73: 222-227.

278. Vance YH, Morse RC, Jenney ME, Eiser C. Issues in Measuring Quality of Life in Childhood Cancer: Measures, Proxies, and Parental Mental Health. Journal of Child Psychology and Psychiatry 2001; 42: 661-667.

279. Vandova G, Surcheva Z. Quality of life of oncohaematologic patients: A pilot study. General Medicine 2008; 10: 11-18.

280. Vellenga E, Van Agthoven M, Croockewit AJ et al. Autologous peripheral blood stem cell transplantation in patients with relapsed lymphoma results in accelerated haematopoietic reconstitution, improved quality of life and cost reduction compared with bone marrow transplantation: the Hovon 22 study. British Journal of Haematology 2001; 114: 319-326.

281. Viala M, Bhakar AL, de la Loge $C$ et al. Patient-reported outcomes helped predict survival in multiple myeloma using partial least squares analysis. Journal of Clinical Epidemiology 2007; 60: 670679.e673.

282. Vlossak D, Fitch MI. Multiple myeloma: the patient's perspective. Can Oncol Nurs J 2008; 18: 141151.

283. Vollmer TC, Wittmann M, Schweiger C, Hiddemann W. Preoccupation with death as predictor of psychological distress in patients with haematologic malignancies. European Journal of Cancer Care 2011; 20: 403-411.

284. Waldmann A, Barragan B, Cursaru V et al. Myeloma Treatment Side Effects and Unmet Patient Needs 2009: Results of An International Comparative Survey Conducted by Myeloma Euronet (ME), the European Network of Myeloma Patient Groups. ASH Annual Meeting Abstracts 2009; 114: 4900 - 
285. Weber CS, Fliege H, Arck PC et al. Patients with haematological malignancies show a restricted body image focusing on function and emotion. European Journal of Cancer Care 2005; 14: 155-165.

286. Weber C, BronnerE, Thier P et al. Body experience and mental representation of body image in patients with haematological malignancies and cancer as assessed with the Body Grid. Br J Med Psychol 2001; 74: 507-521.

287. Wettergren L, Björkholm M, Langius-EklöfA. Validation of an Extended Version of the SEIQoL-DW in a Cohort of Hodgkin Lymphoma' Survivors. Quality of Life Research 2005; 14: 2329-2333.

288. Wettergren L, Sprangers M, Björkholm M, Langius-Eklöf A. Quality of life before and one year following stem cell transplantation using an individualized and a standardized instrument. PsychoOncology 2008; 17: 338-346.

289. Widmark-Petersson V, von Essen L, Sjödén PO. Perceptions of Caring Among Patients With Cancer and TheirStaff: Differences and disagreements. Cancer Nursing 2000; 23: 32-39.

290. Wisløff N, Gulbrandsen F. Health-related Quality of Life and Patients' Perceptions in Interferontreated Multiple Myeloma Patients. Acta Oncologica 2000; 39: 809-813.

291. Wittmann M, VollmerT, Schweiger C, Hiddemann W. The relation between the experience of time and psychological distress in patients with hematological malignancies. Palliative \& Supportive Care 2006; 4: 357-363.

292. Xuereb MC, Dunlop R. The experience of leukaemia and bone marrow transplant: Searching for meaning and agency. Psycho-Oncology 2003; 12: 397-409.

293. Yau E, Rohatiner AZ, ListerTA, Hinds CJ. Long term prognosis and quality of life following intensive care for life-threatening complications of haematological malignancy. British Journal of Cancer 1991; 64: 938-942.

294. Yong K, Alegre AA, Browne P et al. A multicenter, single-arm, open-label safety and quality of life study of lenalidomide plus dexamethasone in previously treated patients with multiple myel oma. Haematologica 2010; 95: 392.

295. Zdebska S, Armata J. [Perception of disease and treatment among older children with hematologic neoplasms]. Pediatr Pol 1981; 56: 969-973. 


\section{Appendix 5:}

\section{Table SI: On-going studies}

\begin{tabular}{|c|c|c|c|c|c|c|}
\hline Study \& country & Study design & $\begin{array}{l}\text { No. of } \\
\text { participants }\end{array}$ & Main aim of study & Study Intervention & $\begin{array}{l}\text { Assessment of patient- } \\
\text { related outcomes }\end{array}$ & Type of patient \\
\hline $\begin{array}{l}\text { OPTIMAL Study }{ }^{43} \\
\text { (Oupatient platelet } \\
\text { transfusions in } \\
\text { myelodysplastic } \\
\text { syndromes and leukemia } \\
\text { (NCT01615146) } \\
\text { Canada }\end{array}$ & $\begin{array}{l}\text { Multi-centre } \\
\text { Open-label } \\
\text { RCT } \\
\text { Feasibility study }\end{array}$ & 60 & $\begin{array}{l}\text { Feasibility study } \\
\text { Overall enrollment } \\
\text { Off protocol transfusions/arm } \\
\text { Total number of plt } \\
\text { transfusions/arm } \\
\text { Patient compliance with daily } \\
\text { self-assessment of bleeding }\end{array}$ & $\begin{array}{l}\text { Intervention: Therapeutic plt transfusions only. } \\
\text { Patients allocated to this group will not receive } \\
\text { routine prophylactic plt transfusions. PIt transfusions } \\
\text { will be given to treat clinically relevant bleeding (WHO } \\
\text { bleeding of grade } 2 \text { or greater). } \\
\text { Control: Prophylactic plt transfusions. Patients } \\
\text { allocated to this group will receive a plt transfusion } \\
\text { when the measured plt count is }<10 \times 10^{9} / \mathrm{L} \text {. }\end{array}$ & EuroQoL-5D & $\begin{array}{l}\text { Adults ( } \geq 18 \text { years) } \\
\text { MDS (including CMML) or AML (WHO } \\
\text { criteria) } \\
\text { Severe thrombocytopenia ( } 2 \text { plt counts } \leq \\
10 \times 10^{9} / \mathrm{L} \geq 7 \text { days a part). } \\
\text { Receiving outpatient supportive or } \\
\text { palliative care } \\
\text { ECOG performance status of } 0-2 \text {. }\end{array}$ \\
\hline $\begin{array}{l}\text { McKenna } 2011^{40} \\
\text { UK }\end{array}$ & $\begin{array}{l}\text { In-depth, one-to- } \\
\text { one qualitative } \\
\text { interviews }\end{array}$ & 30 & $\begin{array}{l}\text { Assess how MDS impacts affects } \\
\text { patients' lives. } \\
\text { Thematic a nalysis using three key } \\
\text { outcomes: Impairments } \\
\text { (symptoms); Activity limitations } \\
\text { and QoL. }\end{array}$ & None & $\begin{array}{l}\text { In-depth, one-to-one } \\
\text { qualitative interviews. } \\
\text { Analysis of QoL issues to } \\
\text { be guided by the needs- } \\
\text { based model of QoL. }\end{array}$ & $\begin{array}{l}\text { MDS } \\
\text { Participants recruited through the MDS } \\
\text { UK Patient Support Group and } \\
\text { Leukaemia CARE. }\end{array}$ \\
\hline
\end{tabular}


$\mathrm{AML}=$ acute myeloid leukaemia; CMML = chronic myelomonocytic leukaemia; ECOG = Eastern Cooperative Oncology Group; plt = platelet; QOL = quality of life; $\mathrm{RCT}$ = randomised controlled trial; WHO $=$ World Health Organization 


\section{Online Table S2: Patient-related Outcome Measures used in included studies}

\begin{tabular}{|c|c|c|c|c|c|c|}
\hline Tool/Scale & $\begin{array}{l}\text { Original design and } \\
\text { specification }\end{array}$ & $\begin{array}{l}\text { Target } \\
\text { group }\end{array}$ & Content & $\begin{array}{l}\text { Administration } \\
\text { and scoring }\end{array}$ & $\begin{array}{l}\text { Validity } \\
\text { and reliability }\end{array}$ & $\begin{array}{l}\text { Comments and concerns with bleeding } \\
\text { /thrombocytopenia }\end{array}$ \\
\hline EQ-5D-3L & $\begin{array}{l}\text { Designed } 1990^{53} \\
\text { Survey to describe HRQoL } \\
\text { in Europe for use in } \\
\text { evaluative studies, policy } \\
\text { research and economic } \\
\text { evaluation } \\
\text { Multidimensional }\end{array}$ & Generic & $\begin{array}{l}5 \text { dimensions relating to deficits in } \\
\text { i) Mobility } \\
\text { ii) Self-care } \\
\text { iii) Usual activity } \\
\text { iv) Anxiety and depression } \\
\text { v) Pain and discomfort } \\
\text { in addition to: } \\
\text { Rating of own health today }\end{array}$ & $\begin{array}{l}\text { Self-administered } \\
\text { Relates to health state today } \\
\text { Range of item responses on } \\
3 \text { point VDS according to } \\
\text { severity. From 'no problems' } \\
\text { to 'extreme problems' or } \\
\text { 'inability to perform tasks'. } \\
\text { VAS to rate own health today } \\
\text { from 'worst imaginable } \\
\text { health state' }(0) \text { to 'best } \\
\text { imaginable health state' } \\
(100) \text {. }\end{array}$ & $\begin{array}{l}\text { Published data } \\
\text { demonstrating } \\
\text { reliabilityand } \\
\text { validity }^{54}\end{array}$ & $\begin{array}{l}\text { Scale does not assess: } \\
\text { 1) presence of bleeding/thrombocytopenia } \\
\text { 2) impact of bleeding/thrombocytopenia } \\
\text { 3) impact of treatment/management of } \\
\text { b) pleeding/thrombocytopenia } \\
\text { 4) psychologicalimpact } \\
\text { Although widelyused in many disease groups it } \\
\text { remains a generic instrument } \\
\text { Recall period may be too short to demonstrate } \\
\text { the impact of bleeding and any } \\
\text { intervention/treatment }\end{array}$ \\
\hline $\begin{array}{l}\text { LGC } \\
\text { Lund } \\
\text { Geronotological } \\
\text { Centre global } \\
\text { quality of life } \\
\text { questionnaire }\end{array}$ & $\begin{array}{l}\text { Designed } 1992^{44} \\
\text { Designed to measure } \\
\text { global QoL in older } \\
\text { people }\end{array}$ & Generic & $\begin{array}{l}\text { 49 items including: } \\
\text { Current quality of life } \\
\text { Mental stability } \\
\text { Life-span quality } \\
\text { Satisfaction with residential environment } \\
\text { Psychosomatic health } \\
\text { Relationships with neighbours } \\
\text { Satisfaction with economic situation } \\
\text { Importance of social activities } \\
\text { Close relationships } \\
\text { View of daily life }\end{array}$ & $\begin{array}{l}\text { Unclear how it is } \\
\text { administered } \\
\text { Scores calculated as a mean } \\
\text { value for all areas or total } \\
\text { mean for all areas. From } 0 \\
\text { (worst possible) to } 1 \text { best } \\
\text { possible) }{ }^{55}\end{array}$ & $\begin{array}{l}\text { Not extensively } \\
\text { validated. Used } \\
\text { in Sweden in } \\
\text { studies of older } \\
\text { people }^{55}\end{array}$ & $\begin{array}{l}\text { Unable to establish if the scale assesses: } \\
\text { 5) presence of bleeding/thrombocytopenia } \\
\text { 6) impact of bleeding/thrombocytopenia } \\
\text { 7) impact of treatment/ma nagement of } \\
\text { bleeding/thrombocytopenia } \\
\text { 8) psychological impact }\end{array}$ \\
\hline $\begin{array}{l}\text { POMS } \\
\text { Profile of Mood } \\
\text { States }\end{array}$ & $\begin{array}{l}\text { Designed } 1971^{56} \\
\text { Measure of subjective } \\
\text { well-being } \\
\text { Originally designed to } \\
\text { assess mood in psychiatric } \\
\text { out-patient attenders }{ }^{56}\end{array}$ & Generic & $\begin{array}{l}65 \text { items measuring } 6 \text { mood states: } \\
\text { i) Tension - Anxiety } \\
\text { ii) Depression - Dejection } \\
\text { iii) Anger - Hostility } \\
\text { iv) Vigour - Activity } \\
\text { v) Fatigue - Inertia } \\
\text { vi) Confusion - Bewilderment }\end{array}$ & $\begin{array}{l}\text { Self-administered } \\
\text { Relates to feelings during } \\
\text { last week including 'today }{ }^{57} \\
\text { Items rated on a 5-point } \\
\text { Likert scale ranging from } 0 \\
\text { (not at all) to } 4 \text { (extremely) } \\
\text { Total mood disturbance } \\
\text { calculated by subtracting the } \\
\text { Vigour subscale score from } \\
\text { the sum of the Tension, }\end{array}$ & $\begin{array}{l}\text { Published data } \\
\text { demonstrating } \\
\text { reliabilityand } \\
\text { validity }^{58}\end{array}$ & $\begin{array}{l}\text { Scale does not assess: } \\
\text { 1) presence of bleeding/thrombocytopenia } \\
\text { 2) impact of bleeding/thrombocytopenia } \\
\text { 3) impact of treatment/management of } \\
\text { bleeding/thrombocytopenia } \\
\text { 4) psychologicalimpact }\end{array}$ \\
\hline
\end{tabular}

Quality of life and bleeding 


\begin{tabular}{|c|c|c|c|c|c|c|}
\hline & & & & $\begin{array}{l}\text { Depression, Anger, Fatigue, } \\
\text { and Confusionsubscale } \\
\text { scores. }\end{array}$ & & \\
\hline $\begin{array}{l}\text { SF-36 } \\
\text { Medical } \\
\text { Outcomes } \\
\text { Study, Short } \\
\text { Form } 36\end{array}$ & $\begin{array}{l}\text { Designed } 1993^{18} \\
\text { For population surveys and } \\
\text { detecting changes in } \\
\text { health status that mightbe } \\
\text { expected to occur from } \\
\text { health service use within a } \\
\text { short time frame. } \\
\text { Discriminates between } \\
\text { people with chronic } \\
\text { disease and general } \\
\text { populations } \\
\text { Multidimensional }\end{array}$ & Generic & $\begin{array}{l}36 \text { items with } 8 \text { dimensions } \\
\text { i) Physical functioning (10) } \\
\text { ii) Social functioning (2) } \\
\text { iii) Role limitations due to physical } \\
\text { problems (4) } \\
\text { iv) Role limitations due to emotional } \\
\text { problems (3) } \\
\text { v) Mental health (5) } \\
\text { vi) Energy/vitality (4) } \\
\text { vii) Pain (2) } \\
\text { viii) General health perception (5) } \\
\text { In addition to perception of health } \\
\text { changes over the past year }\end{array}$ & $\begin{array}{l}\text { Self-administered } \\
\text { Relates to experiences } \\
\text { during the past } 4 \text { weeks; in } \\
\text { general; and compared to } 1 \\
\text { year ago } \\
\text { Range of item responses } \\
\text { from } 3 \text { to } 7 \text { points } \\
\text { Item scores of each } \\
\text { dimension are added } \\
\text { together and calculated } \\
\text { using an algorithm to a scale } \\
\text { of poor health }(0 \%) \text { or good } \\
\text { health }(100 \%)\end{array}$ & $\begin{array}{l}\text { Published data } \\
\text { demonstrating } \\
\text { reliabilityand } \\
\text { validity }{ }^{59}\end{array}$ & $\begin{array}{l}\text { Scale does not assess: } \\
\text { 5) presence of bleeding/thrombocytopenia } \\
\text { 6) impact of bleeding/thrombocytopenia } \\
\text { 7) impact of treatment/ma nagement of } \\
\text { bleeding/thrombocytopenia } \\
\text { 8) psychological impact } \\
\text { Recall period of } 1 \text { month and } 1 \text { year could betoo } \\
\text { long for elderly and/or unwell patients }\end{array}$ \\
\hline $\begin{array}{l}\text { SOC } \\
\text { Sense of } \\
\text { Coherence } \\
\text { Scale }\end{array}$ & $\begin{array}{l}\text { Designed } 1987^{60} \\
\text { Generic scale to assess } \\
\text { coherence as an indicator } \\
\text { of coping with stressful life } \\
\text { situations }^{61}\end{array}$ & Generic & $\begin{array}{l}29 \text { items assessing } 3 \text { elements } \\
\text { i) Comprehensibility (cognitive) (11) } \\
\text { ii) Manageability (instrumental/ } \\
\text { behavioural) (10) } \\
\text { iii) Meaning (motivation) (8) }\end{array}$ & $\begin{array}{l}\text { Self-administered } \\
\text { Relates to experiences "in } \\
\text { past ten years", "until now" } \\
\text { or no time-scale specified } \\
\text { Range of item responses on } \\
\text { a } 7 \text { point NRS. Items are } \\
\text { summed from } 29 \text { to } 203 . \text { A } \\
\text { higher score relates toa } \\
\text { higher sense of } \\
\text { coherence }{ }^{61,62}\end{array}$ & $\begin{array}{l}\text { Published data } \\
\text { demonstrating } \\
\text { reliabilityand } \\
\text { validity }{ }^{60}\end{array}$ & $\begin{array}{l}\text { Scale does not assess: } \\
\text { 1) presence of bleeding/thrombocytopenia } \\
\text { 2) impact of bleeding/thrombocytopenia } \\
\text { 3) impact of treatment/management of } \\
\text { bleeding/thrombocytopenia } \\
\text { 4) psychologicalimpact }\end{array}$ \\
\hline $\begin{array}{l}\text { EORTC } \\
\text { QLQ-C30 } \\
\text { European } \\
\text { Organisation for } \\
\text { Research and } \\
\text { Treatment of } \\
\text { Cancer Quality } \\
\text { of Life } \\
\text { Questionnaire- } \\
\text { Core } 30\end{array}$ & $\begin{array}{l}\text { Designed } 1993^{63} \\
\text { QoL measure for } \\
\text { international cancer trials. } \\
\text { Current version } 3.0 . \\
\text { Multidimensional } \\
\text { Supplementary scales } \\
\text { developed for specific } \\
\text { cancers with unique } \\
\text { problems } \\
\text { Shown to detect changes } \\
\text { over time }\end{array}$ & $\begin{array}{l}\text { Disease: } \\
\text { Cancer }\end{array}$ & $\begin{array}{l}\text { 30 items with } \\
\text { A) } 5 \text { functional scales: } \\
\text { i) Physical } \\
\text { ii) Role } \\
\text { iii) Cognitive } \\
\text { iv) Emotional } \\
\text { v) Social } \\
\text { B) Global health and QoL } \\
\text { C) } 6 \text { single items assess common cancer } \\
\text { symptoms } \\
\text { - Dyspnoea } \\
\text { - Appetite loss } \\
\text { - Sleep disturbance } \\
\text { - Diarrhoea } \\
\text { - Constipation } \\
\text { - Perceived financial impact }\end{array}$ & $\begin{array}{l}\text { Self-administered } \\
\text { Relates to experiences } \\
\text { during the past week } \\
\text { Overall QoL and physical } \\
\text { health condition during the } \\
\text { past week uses a NRS from } \\
\text { 'very poor' (1) to excellent } \\
\text { (7) } \\
\text { Other items } 4 \text { point } \\
\text { response from 'not at all' (1) } \\
\text { to 'very much' (4) } \\
\text { Scales summed up to }\end{array}$ & $\begin{array}{l}\text { Published data } \\
\text { demonstrating } \\
\text { reliabilityand } \\
\text { validity } 64,65\end{array}$ & $\begin{array}{l}\text { Scale does not assess: } \\
\text { 1) presence of bleeding/thrombocytopenia } \\
\text { 2) impact of bleeding/thrombocytopenia } \\
\text { 3) impact of treatment/management of } \\
\text { bleeding/thrombocytopenia } \\
\text { 4) psychological impact of bleeding }\end{array}$ \\
\hline
\end{tabular}

\section{Quality of life and bleeding}




\begin{tabular}{|c|c|c|c|c|c|c|}
\hline & & & $\begin{aligned} & \text { disease/treatment } \\
& \text { D) } 3 \text { symptom scales } \\
&-\quad \text { Fatigue } \\
&-\quad \text { Nausea/vomiting } \\
&-\quad \text { Pain }\end{aligned}$ & produce sub-scale scores & & \\
\hline $\begin{array}{l}\text { FACT- } \\
\text { Functional } \\
\text { Assessment of } \\
\text { Cancer Therapy }\end{array}$ & $\begin{array}{l}\text { Designed in } 1990^{66} \\
\text { Assess HRQoL in cancer, } \\
\text { also include chronic illness } \\
\text { (FACIT). } \\
\text { Modular system of generic } \\
\text { core with specific disease } \\
\text { /symptom 'add-on' } \\
\text { Multidimensional }\end{array}$ & $\begin{array}{l}\text { Disease: } \\
\text { Cancer } \\
\text { Chronic } \\
\text { illness }\end{array}$ & $\begin{array}{l}\text { Core generic (FACT-G) } 27 \text { items with } 4 \\
\text { dimensions } \\
\text { i) Physical well-being (7) } \\
\text { ii) Social/Family well-being (7) } \\
\text { iii) Emotional well-being (6) } \\
\text { iv) Functional well-being (7) } \\
\text { FACT-Th11- } 38 \text { items with } 5 \text { dimensions }{ }^{19} \\
\text { FACT-G (27) plus } \\
\text { v) Additional concerns (11) } \\
\text { FACT-Th18 - } 45 \text { items with } 5 \text { dimensions } 19 \\
\text { FACT-G (27) plus } \\
\text { v) Additional concerns (18) } \\
\text { FACT-BMT- } 50 \text { items with } 5 \text { dimensions }{ }^{19} \\
\text { FACT-G (27) plus } \\
\text { v) Additional concerns (23) }\end{array}$ & $\begin{array}{l}\text { Self-administered } \\
\text { Relates to experiences } \\
\text { during the past week } \\
5 \text { point VDS according to } \\
\text { severity. From 'not at all' (0) } \\
\text { to 'very much'(4). }\end{array}$ & $\begin{array}{l}\text { Publisheddata } \\
\text { demonstrating } \\
\text { reliabilityand } \\
\text { validity in } \\
\text { cancer and } \\
\text { wide range of } \\
\text { chronic } \\
\text { diseases for } \\
\text { FACT-G66,67 and } \\
\text { FACT-BMT. } \\
\text { FACT-Th18 only } \\
\text { tested for } \\
\text { validity in } 108 \\
\text { patients within } \\
\text { urban USA } \\
\text { FACT-Th11 not } \\
\text { tested }\end{array}$ & $\begin{array}{l}\text { Only the FACT-Th Scales assess: } \\
\text { 1) presence of bleeding/thrombocytopenia } \\
\text { 2) impact of bleeding / thrombocytopenia } \\
\text { upon the patient } \\
\text { 3) impact of potential treatment delay due to } \\
\text { bleeding/thrombocytopenia } \\
\text { 1) psychological impact } \\
\text { FACT G and FACT-BMT make no assessment of } \\
\text { bleeding or thrombocytopenia }\end{array}$ \\
\hline $\begin{array}{l}\text { MDASI } \\
\text { MD Anderson } \\
\text { Symptom } \\
\text { Inventory }\end{array}$ & $\begin{array}{l}\text { Designed } 2000^{69} \\
\text { To measure symptom } \\
\text { severity, burden and } \\
\text { interference incancer } \\
\text { Modular system of generic } \\
\text { core with specific disease } \\
\text { /symptom 'add-on' } \\
\text { Multidimensional }\end{array}$ & $\begin{array}{l}\text { Disease: } \\
\text { Cancer }\end{array}$ & $\begin{array}{l}\text { Core generic MDASI } 19 \text { items with } 2 \\
\text { dimensions } \\
\text { Symptom severity items (13): pain, } \\
\text { fatigue, nausea, disturbed sleep, being } \\
\text { distressed, shortness of breath, problems } \\
\text { remembering, lack of appetite, } \\
\text { drowsiness, dry mouth, sadness, } \\
\text { vomiting, numbness/tingling } \\
\text { Symptom interference items (6): general } \\
\text { activity, mood, work; walking, relations } \\
\text { with other people, enjoyment of life } \\
\\
\text { MDASI-BMT } 24 \text { items. Core MDASI (19) } \\
\text { plus additional symptom severity items } \\
\text { (5): feeling physically sick; feeling } \\
\text { physically weak; diarrhoea; mouth sores, }\end{array}$ & $\begin{array}{l}\text { Self-administered } \\
\text { Relates to symptoms } \\
\text { experienced during last } 24 \\
\text { hours } \\
0 \text { to } 10 \text { point NRS to assess } \\
\text { severity of symptoms and } \\
\text { interference. From 'not } \\
\text { present/did not interfere' (0) } \\
\text { to 'as bad you can } \\
\text { imagine/completely } \\
\text { interfered' (10) }\end{array}$ & $\begin{array}{l}\text { Published data } \\
\text { demonstrating } \\
\text { reliabilityand } \\
\text { validity in } \\
\text { cancer for core } \\
\text { MDASI } 69,70 \text {. } \\
\text { MDASI-BMT not } \\
\text { validated. }\end{array}$ & $\begin{array}{l}\text { The MDASI-BMT asks one question relating to } \\
\text { the presence of bleeding at its worst only } \\
\text { Scale does not assess: } \\
\text { 1) impact of bleeding/thrombocytopenia } \\
\text { 2) impact of treatment/ma nagement of } \\
\text { bleeding/thrombocytopenia } \\
\text { 3) psychological impact } \\
\text { Recall period may be too short to demonstrate } \\
\text { the impact of bleeding and any } \\
\text { intervention/treatment }\end{array}$ \\
\hline
\end{tabular}

Quality of life and bleeding 
1 10 bleeding

EORTC = European Organization for Research and Treatment of Cancer; FACT-BMT = Functional ass essment of Cancer Therapy - Bone Marrow Transplantation; FACT-G = Functiona I as sess m ent of Cancer Therapy-General; FACT-Th = Functional assessment of Cancer Therapy-Thrombocytopenia; MDASI-BMT = MD Anderson Symptom Inventory- Bone Marrow Transplant; NRS = nu meric al rating scale; POMS = Profile of Mood States; QoL = Quality of Life;SF-36 = Short Form 36; VAS = Visual Anal ogue Scale; VDS = Verbal Descriptor Scale 